\title{
Weight gain in smokers after quitting cigarettes: meta-analysis
}

\author{
(ब) $(\mathbb{O} \Theta$ OPEN ACCESS
}

\author{
Henri-Jean Aubin professor of psychiatry and addiction medicine ${ }^{12}$, Amanda Farley research fellow \\ ${ }^{3}$, Deborah Lycett National Institute for Health Research school for primary care research fellow ${ }^{3}$, \\ Pierre Lahmek gastroenterologist ${ }^{2}$, Paul Aveyard professor of behavioural medicine ${ }^{3}$
}

${ }^{1}$ Centre d'Enseignement, de Recherche et de Traitement des Addictions, Hôpital Paul Brousse, AP-HP, Univ Paris-Sud, INSERM U669, 94804 Villejuif, France; ${ }^{2}$ Centre de Traitement des Addictions, Hôpital Emile Roux, Limeil-Brévannes, France; ${ }^{3}$ UK Centre of Tobacco Control Studies, Primary Care Clinical Sciences, University of Birmingham, Birmingham, UK

\begin{abstract}
Objective To describe weight gain and its variation in smokers who achieve prolonged abstinence for up to 12 months and who quit without treatment or use drugs to assist cessation.

Design Meta-analysis.

Data sources We searched the Central Register of Controlled Trials (CENTRAL) and trials listed in Cochrane reviews of smoking cessation interventions (nicotine replacement therapy, nicotinic partial agonists, antidepressants, and exercise) for randomised trials of first line treatments (nicotine replacement therapy, bupropion, and varenicline) and exercise that reported weight change. We also searched CENTRAL for trials of interventions for weight gain after cessation.
\end{abstract}

Review methods Trials were included if they recorded weight change from baseline to follow-up in abstinent smokers. We used a random effects inverse variance model to calculate the mean and $95 \%$ confidence intervals and the mean of the standard deviation for weight change from baseline to one, two, three, six, and 12 months after quitting. We explored subgroup differences using random effects meta-regression.

Results 62 studies were included. In untreated quitters, mean weight gain was $1.12 \mathrm{~kg}$ (95\% confidence interval 0.76 to 1.47$), 2.26 \mathrm{~kg}(1.98$ to 2.54 ), $2.85 \mathrm{~kg}$ (2.42 to 3.28 ), $4.23 \mathrm{~kg}$ (3.69 to 4.77 ), and $4.67 \mathrm{~kg}$ (3.96 to 5.38 ) at one, two, three, six, and 12 months after quitting, respectively. Using the means and weighted standard deviations, we calculated that at 12 months after cessation, $16 \%, 37 \%, 34 \%$, and $13 \%$ of untreated quitters lost weight, and gained less than $5 \mathrm{~kg}$, gained $5-10 \mathrm{~kg}$, and gained more than $10 \mathrm{~kg}$, respectively. Estimates of weight gain were similar for people using different pharmacotherapies to support cessation. Estimates were also similar between people especially concerned about weight gain and those not concerned.

Conclusion Smoking cessation is associated with a mean increase of 4-5 kg in body weight after 12 months of abstinence, and most weight gain occurs within three months of quitting. Variation in weight change is large, with about $16 \%$ of quitters losing weight and $13 \%$ gaining more than $10 \mathrm{~kg}$.

\section{Introduction}

Although smoking cessation results in considerable improvements in health, it is often accompanied by weight gain. The link between smoking and body weight has been known for many years. Cross sectional studies show that, on average, smokers weigh less than non-smokers, and former smokers weigh more than both smokers and non-smokers. ${ }^{1}$ A large prospective study has shown that adolescents who initiate smoking gain less weight than their non-smoking peers. ${ }^{2}$ Cohort studies also show that people who stop smoking gain weight. ${ }^{13-8}$ Smoking cessation probably causes weight gain because nicotine (in cigarettes) is an appetite suppressant. ${ }^{3}$ One of the most common and longlasting symptoms of tobacco withdrawal is increased appetite. ${ }^{9}$ Furthermore, evidence suggests that nicotine increases the basal metabolic rate, and removal of this effect results in a decline in energy expenditure at a time when appetite is increased. ${ }^{3}$

Estimates of the amount of weight that smokers gain when quitting have varied. A large narrative systematic review ${ }^{1}$ done over 20 years ago concluded that weight gain from smoking cessation was typically $2.9 \mathrm{~kg}$, and this estimate or similar is often quoted in smoking cessation advice leaflets. However, the review did not describe the method of combining estimates, and could have provided an inaccurate estimate of weight gain for several reasons. Firstly, follow-up periods in the 41 prospective studies reviewed varied from two weeks to 40 years. Secondly, measures of both smoking and weight were often self reported, without validation. Thirdly, the definition of smoking cessation was often not clear and probably included people who were "point prevalent" abstinent at the time of follow-up. 
People who meet the definition of point prevalence abstinence will include those who have been continuously or intermittently abstinent for years, or those who have recently stopped only days or weeks before measurement. Point prevalence abstinence was more likely to have been used in the population based studies included in this review, such as the Framingham study, ${ }^{10}$ because participants were not given a target quit date and followed from that point. A previous study has shown that the mean weight gain in studies measuring point prevalence abstinence was lower than those measuring weight change in continuous abstainers. ${ }^{11}$

We aimed to describe weight changes seen in smokers who were motivated to quit. Data in this study were derived from clinical trials of first line smoking cessation drugs and from trials of interventions designed to limit weight gain after cessation. We previously published a Cochrane review that examined the effectiveness of these interventions on preventing such weight gain in the short term and at six and 12 month follow-up in full detail. ${ }^{12}$ The three treatments commonly used around the world are nicotine replacement therapy, bupropion, and varenicline. In brief, the Cochrane review showed that all three treatments reduced weight gain by $0.5 \mathrm{~kg}$ (nicotine replacement therapy), $1.1 \mathrm{~kg}$ (bupropion), and $0.4 \mathrm{~kg}$ (varenicline). There was no evidence that any of them reduced weight gain at one year, but the data were too imprecise to exclude effects of similar size. In the present study, rather than describing the effect of treatment on limiting weight gain, we described the weight change over time, and its variability between individuals for smokers who quit using these treatments, and for those who quit without using them, during the first 12 months of abstinence.

\section{Methods}

The aim of this study was to estimate the mean weight change, and the variation around the mean of that change, in smokers who presented for smoking cessation treatment and achieve abstinence. Most data were derived from clinical trials of first line interventions for smoking cessation, published in Cochrane reviews. The primary aim of most of the reviewed trials was to assess the effectiveness of the pharmacological interventions to assist quitting. These data and adverse event data were summarised in the relevant Cochrane reviews. ${ }^{13-17} \mathrm{We}$ used these trials to estimate mean weight change and its variation in untreated quitters (control arm data) and treated quitters (treatment arm data).

A second group of trials examined the effectiveness of specific interventions to prevent weight gain after cessation. Such trials typically enrolled smokers especially concerned about gaining weight and randomised them to standard support for smoking cessation or standard support plus an intervention to prevent weight gain. Here, we used data from the control groups only because some of these interventions were effective in reducing weight gain. ${ }^{12}$ We used these data to estimate weight change in weight concerned smokers, because some authors have shown increased weight gain in this group. ${ }^{18}$

A third group of studies examined the effectiveness of exercise in promoting smoking cessation. A systematic review of randomised trials showed convincing evidence indicating that exercise suppresses cravings to smoke. Most trials of exercise in the Cochrane review on the effect of exercise on cessation did not report data for weight gain nor appeal to weight concerned smokers. ${ }^{17}$ Nevertheless, exercise could reduce weight gain, ${ }^{12}$ and we included only the control arms of these trials to estimate weight change in untreated quitters.

\section{Search strategy and study selection}

Trials included in this study were identified from our Cochrane review on interventions to prevent weight gain. ${ }^{12}$ The search was updated in November 2011, and is reported in detail elsewhere. In brief, we searched the included lists of Cochrane reviews of smoking cessation interventions-nicotine replacement therapy (last search date, October 2007), ${ }^{15}$ antidepressants (July 2009), ${ }^{16}$ nicotine receptor partial agonists (October 2010), ${ }^{13}$ and exercise interventions (July 2011) $)^{17}$ - published in version 11 of the 2011 Cochrane Library. We updated the searches for nicotine replacement therapy, bupropion, varenicline, and exercise trials published since the last search date for each Cochrane review to November 2011 by searching the Cochrane CENTRAL register (Central Register of Controlled Trials) using a combination of smoking and treatment search terms. In addition, we searched the Cochrane Tobacco Addiction Group specialist register for interventions that specifically targeted weight gain after cessation in addition to smoking cessation (search date, November 2011), using a combination of smoking and weight related search terms.

For inclusion in our review, studies had to report or their authors had to supply data for weight change from baseline to at least one follow-up point in abstainers only. Almost all studies of nicotine replacement therapy, varenicline, bupropion, and exercise did not report weight data in either the title or abstract. Consequently, we assessed the full text of every study in the latest versions of the reviews of effectiveness of the four treatments for inclusion. For the update search, we obtained and read the full text of every trial, if the title or abstract made it apparent that it was a trial of one of these interventions. We contacted authors or sponsors (or both) if weight data were incompletely recorded or missing but it was clear that participants had been weighed. Likewise, we screened the full text of any trial in which the title or abstract clearly indicated that the intervention aimed to allay concern about weight gain after cessation or aimed to prevent such weight gain. Studies in foreign languages were translated into English.

\section{Data extraction}

Three authors (H-JA, AF, DL) extracted data, with each study having data extracted by two independent authors. Remaining differences were resolved by a fourth author (PA) extracting data and thereafter by consensus. We extracted the mean weight change $(\mathrm{kg})$, standard deviation, and number of participants contributing to the mean from baseline to each given time point, in abstinent smokers only. Time points were calculated in reference to the target quit date. Time points were aggregated into months (weeks two to five $=$ month one; weeks six to nine $=$ month two; weeks $10-13=$ month three; weeks 22-26=month six; weeks 50-56=month 12 .

\section{Study quality assessment}

Although the data were derived from randomised controlled trials, weight gain was not considered by randomisation group, and therefore we treated the data as observational. As such, we based our assessment of quality on the framework proposed by Altman, a widely cited framework tailored to the assessment of descriptive cohort studies. ${ }^{19}$ Study quality was mainly based on the assessment of smoking status and weight (table $1 \Downarrow)$. We assessed whether studies reported smoking abstinence as prolonged or continuous - that is, whether participants had sufficient time for weight gain to occur, or had point prevalence abstinence. In addition, a proportion of patients treated in clinics can claim abstinence even if they have not achieved it. 
Biochemical validation would reduce the number of people falsely claiming abstinence, which would underestimate weight gain if such participants were included; therefore, we also extracted data regarding the use of biochemical validation. Finally, we examined whether studies reported how weight was assessed, and we categorised studies that obtained self reported weights, which are known to be subject to error, ${ }^{20}$ from those studies in which people were weighed.

\section{Data analysis}

We combined data to describe weight change in quitters treated with varenicline, bupropion, or nicotine replacement therapy, and in those who were not given these treatments ("untreated quitters"). To estimate weight change in the untreated quitters, we combined data from the control group of trials of nicotine replacement therapy, varenicline, bupropion, and exercise for smoking cessation, and from the control group of trials of interventions to prevent or allay concerns about weight gain after cessation. Treated quitter groups included data from the active treatment arm of trials of nicotine replacement therapy, varenicline, and bupropion. We kept these groups separate because these pharmacotherapies could have a small effect on weight gain in the short term. ${ }^{12} \mathrm{We}$ combined studies with multiple treatment arms of the same pharmacotherapy (that is, testing different dose regimens or preparations). Control groups in which participants received one form of pharmacotherapy were not included in the meta-analysis for untreated quitters, but rather in the corresponding treatment group. We excluded treatment groups that received more than one pharmacotherapy.

We used a random effects inverse variance model to estimate a summary mean for weight change and $95 \%$ confidence intervals at months one, two, three, six, and 12 for each of the groups described above. The random effects model was chosen because of the high heterogeneity between trial estimates in each meta-analysis. The underlying assumption of a random effects model is that the true effect could vary between studies, based on characteristics of the study population or intervention. In this case, for example, the population mean might differ if participants are younger; healthier, by baseline body mass index or previous quit history; or if the study used a more intensive or longer intervention.

The studies in the meta-analysis were assumed to be a random sample of the relevant distribution of effects, and the combined effect estimated the mean effect of these different subpopulation means. We measured heterogeneity using the $\mathrm{I}^{2}$ statistic. We also estimated the variation in weight change by calculating a weighted mean (according to the number participants in the study) of the standard deviations. Using z scores, we calculated the percentage of the quitting population who would be expected to lose weight, remain stable, gain less than $5 \mathrm{~kg}$, gain $5-10 \mathrm{~kg}$, or gain more than $10 \mathrm{~kg}$ over 12 months. We assumed that weight change after cessation is roughly normally distributed. We believe this assumption is reasonable; data from our trials suggest weight gain after cessation is normally distributed. ${ }^{21} 22$ Also, other trials have reported means and standard deviations rather than medians and interquartile ranges, which they might have reported if data were skewed. We did all analyses using the Comprehensive Meta Analysis statistical program (version 2.2.50) and Stata (version 10).

\section{Subgroup analyses}

Owing to the heterogeneity present, we sought to identify subgroups with differing mean weight gain. We combined data from all studies at 12 month follow-up, using a random effects metaregression model with a binary predictor variable for weight concern. Twelve month data were used, because any effect of treatment on weight has not been shown to persist beyond this follow-up point. ${ }^{12}$

\section{Sensitivity analyses}

We evaluated the effect of study quality criteria on estimates of weight change in data from all studies combined at 12 month follow-up, using a random effects meta-regression model. We used binary predictor variables to assess whether the mean weight change differed in studies defining abstinence as point prevalence abstinence versus prolonged or continuous abstinence, and whether weight was measured at the clinic or elsewhere, at each follow-up point. It was not possible to test the effect of biochemical confirmation of abstinence, because all but one study confirmed abstinence biochemically.

\section{Publication bias}

Most trials assessed did not report weight gain, and it is possible that trials chose to report weight gain only if the gain was remarkably high. We constructed funnel plots for weight estimates for untreated patients and patients treated with nicotine replacement therapy, bupropion, and varenicline at three and 12 months to test for plot symmetry, in order to detect any publication bias.

\section{Results}

\section{Included studies}

Of 212 trials in the Cochrane reviews of nicotine replacement therapy, varenicline, bupropion, and exercise, 53 recorded weight change at one or more follow-ups (fig $1 \Downarrow$ ). We also found another trial with weight data in the updated search. Of these 54 trials, three were excluded because all groups received some intervention that could affect weight gain. The search of online databases for studies aimed at preventing weight gain after cessation led to the full text search of 16 studies. Of these, 11 were included and an additional two were already found from searches of the Cochrane reviews. The three excluded trials all offered interventions that might limit weight gain to all participants. In total, we included 62 trials.

\section{Description of studies and quality assessment}

Studies often had eligible data from more than one trial arm (control and treatment arms), and some studies contributed data for more than one treatment. In total, 51 studies contributed weight change data in participants under control conditions (untreated quitters). Nine of these studies tested interventions to limit weight gain and largely recruited weight concerned smokers. ${ }^{21}{ }^{23-30}$ Data for weight gain in smokers taking nicotine replacement therapy (any preparation, any strength), bupropion (300 mg/day), and varenicline ( $2 \mathrm{mg} /$ day) were collected from 34,10 , and 12 studies, respectively. Of the 62 included trials, 59 enrolled populations from North America, Europe, or Australia, and the remaining three ${ }^{31-33}$ were conducted in east Asian countries (table $2 \Downarrow$ ). One study ${ }^{30}$ reported weight change at months three, six, and nine. Since this study was the only one with a nine month time point, we did not include the data at nine months. We could not extract data for weight gain by sex, because it was not presented in any study. Seven studies recruited women only. 23252930353686 One of these studies investigated exercise, and the remaining trials analysed interventions for weight gain after cessation. All other trials recruited both men and women. 
Overall, studies were of high quality. Fifty one studies measured weight change in abstinent smokers, using the definition of prolonged abstinence or continuous abstinence from the first day of quitting. All but one of these studies validated abstinence biochemically. ${ }^{37}$ Two other studies had definitions similar to the Russell standard criterion for prolonged abstinence and we counted them as such. ${ }^{38}$ One study allowed participants to "slip up" for up to seven consecutive days, ${ }^{39}$ and another ${ }^{40}$ allowed patients to have up to three cigarettes per week but verified them as abstinent by carbon monoxide measurement. Eight studies $^{23} 24$ 41-45 defined abstinence as biochemically validated point prevalence at seven days. One study ${ }^{46}$ did not define abstinence.

Two studies used self reported weight $\mathrm{t}^{37}$ and 33 reported (or authors or sponsors confirmed) weighing participants. Twenty six studies did not report whether participants were weighed or data were self reported. We recorded weight assessment in these studies as unclear, although all studies but one ${ }^{46}$ biochemically validated abstainers at follow-up (and therefore must have had a face-to-face meeting) and therefore probably measured participants' weight rather than using participants' self reported weight. No studies reported details of weight measurement such as validated scales or clothing requirements.

\section{Effect on weight gain}

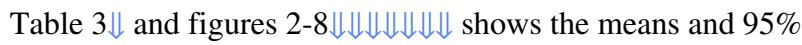
confidence intervals for weight change from baseline in treated and untreated smokers during the first 12 months of abstinence. In all groups, weight increased by about $1 \mathrm{~kg}$ per month for the first three months. Thereafter, the rate of increase reduced, leading to an estimated weight increase of about $4-5 \mathrm{~kg}$ at one year after cessation.

There were small differences in the estimates between different pharmacotherapies. We did not test for the significance of these differences because these data were available in the Cochrane review. ${ }^{12}$ Table 3 shows weighted mean standard deviations, which indicated a large variation between participants. Using $\mathrm{z}$ scores, we calculated the percentage of the quitting population who would be expected to lose weight, remain stable, gain less than $5 \mathrm{~kg}$, gain $5-10 \mathrm{~kg}$, or gain more than $10 \mathrm{~kg}$ over 12 months (figs 9-11 $\Downarrow \downarrow \Downarrow$ ). At 12 months, 16-21\% of untreated participants lost weight, 35-38\% gained less than $5 \mathrm{~kg}, 29-34 \%$ gained 5-10 $\mathrm{kg}$, and $13-14 \%$ of participants gained more than $10 \mathrm{~kg}$. These proportions were similar for participants who had used first line treatment for smoking cessation.

\section{Subgroup analyses}

We found no clear difference between the mean weight gain in studies that treated weight concerned smokers and those that treated the general population of smokers (table $4 \Downarrow$ ). Therefore, the findings reported above and in table 3 include all data regardless of study participant selection for weight concern.

\section{Sensitivity analyses and publication bias}

Weight gain at 12 months was lower in trials that recorded abstinence as point prevalence, than in those that measured weight in prolonged or continuous abstainers, although this difference was not significant $(3.80 \mathrm{~kg}(95 \%$ confidence interval 2.31 to 5.29$) v 4.74 \mathrm{~kg}$ (4.33 to 5.16), $\mathrm{P}=0.14)$. We found no significant difference at all time points in weight gain between trials that measured weight at the clinic or when weight was reported otherwise. All studies reporting weight data at 12 months biochemically confirmed abstinence; therefore, sensitivity analysis by this study quality variable was not performed. No funnel plot showed evidence of asymmetry, providing good evidence that the trials represent a random selection of weight change estimates. Plots are available on request from the authors.

\section{Discussion}

Our meta-analysis has shown that abstinent smokers gain a mean weight of $4-5 \mathrm{~kg}$ after 12 months of abstinence. However, we have found substantial variation in weight gain, indicating that this mean value does not reflect many people who give up smoking. We estimated that at 12 months, $16-21 \%$ of participants lost weight and 13-14\% gained more than $10 \mathrm{~kg}$.

Although weight gain after smoking cessation is widely recognised, this meta-analysis provides clinicians and patients with a more robust and detailed description of the first 12 months of weight change after cessation. The finding of a mean weight gain of $4.7 \mathrm{~kg}$ in untreated quitters at one year after smoking cessation is substantially higher than the $2.9 \mathrm{~kg}$ often quoted in smoking cessation advice leaflets, which stemmed from a previous review. ${ }^{1}$ Moreover, this mean weight gain is greater than the $2.3 \mathrm{~kg}$ gain that female smokers report being willing to tolerate, on average, before embarking on a quit attempt. $^{48}$

This review reports on variation in weight gain, which is rarely described or discussed in the literature, and has clinical implications. Some people are either destined or able to prevent weight gain without intervention, whereas others seem likely to gain enough weight that puts them at increased risk of diabetes, among other complications. ${ }^{49}$ In practice, doctors could detect people gaining excessive weight and intervene early to prevent this.

We were unable to show a significant difference between weight change estimates in point prevalence abstainers and prolonged or continuous abstainers, and therefore, we combined all estimates at each time point regardless of abstinence definition. This may be because the data were derived from clinical trials, in which participants were all given the same target quit date, and therefore many point prevalence abstainers were also prolonged abstainers. ${ }^{50}$ However, the point estimate did indicate a smaller weight change in point prevalence abstainers and it is possible that this difference was the case in our analysis, although it was not sufficiently powered to detect statistical significance.

Most trials aimed at preventing weight gain typically enrolled weight concerned women, but did not provide clear evidence that this group were at risk of greater weight gain. This result might seem surprising, since people concerned about weight may have experienced excessive weight gain in previous quit attempts, and excessive gain is associated with greater weight gain in a current quit attempt. ${ }^{51}$ However, the association between weight concerns and weight gain after cessation is unclear. ${ }^{18} 5253$ Furthermore, nearly all such trials recruited exclusively women, whereas trials appealing to the general population were all mixed sex. Consequently, the data were inevitably confounded and also not precise enough to exclude a difference between weight concerned populations and populations not specifically concerned about weight gain.

Our estimates provided the difference between starting weight and weight up to one year later. The mean weight of a population is likely to increase over one year independently of a smoking cessation attempt. ${ }^{54}$ The Lung Health Study showed that continuing smokers gain on average of $0.3 \mathrm{~kg} /$ year for men and $0.5 \mathrm{~kg} /$ year for women. ${ }^{55}$ Another study ${ }^{7}$ estimated a gain of about $0.3 \mathrm{~kg} /$ year for both sexes, meaning that roughly $4.3 \mathrm{~kg}$ 
of the mean weight gain at 12 months in our analysis was due to cessation (table 3).

These data relate only to weight gain in people who achieve and maintain abstinence, but provide no evidence on what happens to weight in smokers who are abstinent and then relapse or in continuing smokers who never achieve abstinence. For smokers who gain weight on cessation, available data suggest that they lose weight again if they relapse to smoking ${ }^{56}$ although few studies have reported data for weight gain in those who relapse. An incremental weight gain would be important because many people repeatedly attempt to quit. Furthermore, because few trials followed participants beyond one year, we cannot report here on weight gain beyond this time point. Evidence is conflicting as to whether weight continues to increase beyond the first year after cessation. ${ }^{557-59}$

We limited our review to randomised controlled trials for smoking cessation, pharmacotherapy use, exercise, and interventions aiming to prevent weight gain. The validity of data for weight gain after cessation depends on accurate timing of the start of abstinence, the validity of recording of abstinence, and frequent follow-up. Most of the trials we reviewed show these features but few observational studies do. We also limited our review to trials in the Cochrane reviews of first line treatment, which led to the exclusion of a few other trials, chiefly the Lung Health Study ${ }^{55}$ However, estimates of the effect of cessation on weight gain at one year from the Lung Health Study were similar to our estimates, and there was no reason to presume that using data from only randomised controlled trials created a bias.

\section{Limitations}

These data were derived from smokers treated in clinics for tobacco dependence. Such groups are usually more dependent and heavier smokers than the general population of smokers.

There is conflicting evidence that heaviness of smoking relates to weight gain, ${ }^{4}$ with different studies reporting that heavier smokers gain more weight, or that moderate smokers gain most weight. Smokers seeking treatment could differ from those who quit on their own in other ways. Most people do not attend smoking cessation clinics or consult their doctor for help until they have tried and failed to stop smoking themselves. Their previous failure to accomplish one goal, smoking cessation, could reflect on their ability to limit weight gain after cessation. This theory is speculative, however. The differences between the population enrolled in clinical treatment and smokers quitting without clinical help could be related to weight gain after cessation. A systematic review of population based studies, taking careful account of the assessment of continuing abstinence, would be needed to assess weight gain after smoking cessation in the general population. Therefore, our review data are directly relevant to clinicians who only treat smokers who present for help with cessation.

Weight gain was reported in only $25 \%$ of the smoking cessation trials considered for inclusion. It was not possible to determine whether those studies reporting weight were a biased sample of all smoking cessation trials, although we found no evidence of bias on the funnel plot. Trials that aimed to prevent weight gain after cessation reported weight change as a primary outcome, and we observed no difference in weight gain between these trials and the treatment trials, in which only a minority reported weight gain.

Different studies, and therefore different study participants, contributed data to the meta-analyses at each time point and we noted heterogeneity in most analyses. We therefore cannot interpret mean weight change across different time points as a trajectory. Studies would need to report individual weight gain trajectories, rather than cross sectional means, for us to summarise these changes. Large weight gain might lead to intentional relapse to smoking, which would mean that people who put on large amounts of weight early in their quit attempt and relapse were not represented by our data. However, data are conflicting for the association between weight gain and probability of relapse. ${ }^{51}$ 60-68

\section{Conclusions}

Previous reports have underestimated the average amount of weight gained when people stop smoking. In clinic treated smokers, the population mean is about $4-5 \mathrm{~kg}$ after 1 year. Weight gain is greatest during the first three months of quitting (average monthly weight gain of about $1 \mathrm{~kg}$ ), after which the rate of increase declines. However, we saw a large variation around the population mean. At 12 months, about $16-21 \%$ of participants lost weight and $13-14 \%$ gained more than $10 \mathrm{~kg}$.

Weight gain is important because weight concern is widespread among smokers and could deter some from trying to quit. Gaining weight after cessation limits some of the health benefits of quitting and is associated with an increased risk of health problems. ${ }^{69-73}$ So far, interventions have had a limited effect on preventing weight gain. ${ }^{12}$ These data suggest that doctors might usefully give patients a range of expected weight gain, although further research should identify the subgroups most at risk of gaining weight and clarify the optimum content and timing of interventions to prevent weight gain after cessation.

Contributors: H-JA, AF, PL, and PA contributed to the planning; all authors contributed to the drafting, revising, and final approval of the article; and $\mathrm{H}-\mathrm{JA}, \mathrm{AF}$, and $\mathrm{PA}$ are responsible for the overall content as guarantors of the study.

Funding: The study received no special funding for this research. The team in the United Kingdom are funded by the UK Centre for Tobacco Control Studies, a Public Health Research Centre of Excellence of the UK Clinical Research Collaboration. The centre is funded by the British Heart Foundation, Cancer Research UK, Economic and Social Research Council, Medical Research Council, and the Department of Health, under the auspices of the UK Clinical Research Collaboration. PA is part funded by the National Institute for Health Research.

Competing interests: All authors have completed the Unified Competing Interest form at www.icmje.org/coi_disclosure.pdf (available on request from the corresponding author) and declare: support from the UK Centre of Tobacco Control Studies, British Heart Foundation, Cancer Research UK, Economic and Social Research Council, Medical Research Council, Department of Health, and National Institute for Health Research; H-JA has received sponsorship to attend scientific meetings, speaker honorariums, and consultancy fees from Pfizer, McNeil, GlaxoSmithKline, Pierre-Fabre Sante, Sanofi-Aventis, and Merck-Lipha; PA has done consultancy and research on behalf of the McNeil, Pfizer, and Celtic Biotechnology; no other relationships or activities that could appear to have influenced the submitted work.

Data sharing: No additional data available.

1 Klesges RC, Meyers AW, Klesges LM, La Vasque ME. Smoking, body weight, and their effects on smoking behavior: a comprehensive review of the literature. Psychol Bull 1989;106:204-30.

2 Fidler JA, West R, Van Jaarsveld CH, Jarvis MJ, Wardle J. Does smoking in adolescence affect body mass index, waist or height? Findings from a longitudinal study. Addiction 2007;102:1493-501.

3 Filozof C, Fernandez Pinilla MC, Fernandez-Cruz A. Smoking cessation and weight gain. Obes Rev 2004;5:95-103.

4 Froom P, Melamed S, Benbassat J. Smoking cessation and weight gain. J Fam Pract 1998;46:460-4.

5 Perkins KA. Weight gain following smoking cessation. J Consult Clin Psychol 1993;61:768-77. 


\section{What is already known on this topic}

Smoking cessation is often followed by an increase in bodyweight, but estimates vary and are not well grounded

\section{What this study adds}

Smoking cessation is associated with a mean increase in body weight of about $4-5 \mathrm{~kg}$ after 1 year, with most weight gain occurring within three months of quitting

Changes in body weight vary widely, with around $16 \%$ of quitters losing weight and $13 \%$ gaining more than $10 \mathrm{~kg}$

6 Pistelli F, Aquilini F, Carrozzi L. Weight gain after smoking cessation. Monaldi Arch Chest Dis 2009;71:81-7.

7 Lycett D, Munafo M, Johnstone E, Murphy M, Aveyard P. Associations between weight change over 8 years and baseline body mass index in a cohort of continuing and quitting smokers. Addiction 2010;106:188-96.

8 Eisenberg D, Quinn BC. Estimating the effect of smoking cessation on weight gain: an instrumental variable approach. Health Serv Res 2006;41:2255-66.

9 Hughes JR. Effects of abstinence from tobacco: etiology, animal models, epidemiology, and significance: a subjective review. Nicotine Tob Res 2007;9:329-39.

10 Gordon T, Kannel WB, Dawber TR, McGee D. Changes associated with quitting cigarette smoking: the Framingham Study. Am Heart J 1975;90:322-8.

11 Klesges RC, Winders SE, Meyers AW, Eck LH, Ward KD, Hultquist CM, et al. How much weight gain occurs following smoking cessation? A comparison of weight gain using both continuous and point prevalence abstinence. J Consult Clin Psychol 1997;65:286-91.

12 Farley AC, Hajek P, Lycett D, Aveyard P. Interventions for preventing weight gain after smoking cessation. Cochrane Database Syst Rev 2012;1:CD006219.

13 Cahill K, Stead LF, Lancaster T. Nicotine receptor partial agonists for smoking cessation. Cochrane Database Syst Rev 2011;2:CD006103.

14 Cahill K, Ussher MH. Cannabinoid type 1 receptor antagonists for smoking cessation. Cochrane Database Syst Rev 2011;3:CD005353.

15 Stead LF, Perera R, Bullen C, Mant D, Lancaster T. Nicotine replacement therapy for smoking cessation. Cochrane Database Syst Rev 2008;1:CD000146.

16 Hughes JR, Stead LF, Lancaster T. Antidepressants for smoking cessation. Cochrane Database Syst Rev 2007;1:CD000031.

17 Ussher MH, Taylor A, Faulkner G. Exercise interventions for smoking cessation. Cochrane Database Syst Rev 2008;4:CD002295.

18 Borrelli B, Mermelstein R. The role of weight concern and self-efficacy in smoking cessation and weight gain among smokers in a clinic-based cessation program. Addict Behav 1998;23:609-22.

19 Altman DG. Systematic reviews of evaluations of prognostic variables. BMJ 2001:323:224-8.

20 Villanueva EV. The validity of self-reported weight in US adults: a population based cross-sectional study. BMC Public Health 2001;1:11.

21 Parsons A, Ingram J, Inglis J, Aveyard P, Johnstone E, Brown K, et al. A proof of concept randomised placebo controlled factorial trial to examine the efficacy of St John's wort for smoking cessation and chromium to prevent weight gain on smoking cessation. Drug Alcohol Depend 2009:102:116-22.

22 Aveyard P, Johnson C, Fillingham S, Parsons A, Murphy M. Nortriptyline plus nicotine replacement versus placebo plus nicotine replacement for smoking cessation: pragmatic randomised controlled trial. BMJ 2008;336:1223-7.

23 Cooper TV, Klesges RC, Debon MW, Zbikowski SM, Johnson KC, Clemens LH. A placebo controlled randomized trial of the effects of phenylpropanolamine and nicotine gum on cessation rates and postcessation weight gain in women. Addict Behav 2005;30:61-75.

24 Hall SM, Tunstall CD, Vila KL, Duffy J. Weight gain prevention and smoking cessation: cautionary findings. Am J Public Health 1992;82:799-803.

25 Levine MD, Perkins KA, Kalarchian MA, Cheng Y, Houck PR, Slane JD, et al. Bupropion and cognitive behavioral therapy for weight-concerned women smokers. Arch Intern Med 2010;170:543-50.

26 Norregaard J, Jorgensen S, Mikkelsen KL, Tonnesen P, Iversen E, Sorensen T, et al. The effect of ephedrine plus caffeine on smoking cessation and postcessation weight gain. Clin Pharmacol Ther 1996;60:679-86.

27 O'Malley SS, Cooney JL, Krishnan-Sarin S, Dubin JA, McKee SA, Cooney NL, et al. A controlled trial of naltrexone augmentation of nicotine replacement therapy for smoking cessation. Arch Intern Med 2006;166:667-74.

28 Perkins KA, Marcus MD, Levine MD, D'Amico D, Miller A, Broge M, et al. Cognitive-behavioral therapy to reduce weight concerns improves smoking cessation outcome in weight-concerned women. J Consult Clin Psychol 2001;69:604-13.

29 Pirie PL, McBride CM, Hellerstedt W, Jeffery RW, Hatsukami D, Allen S, et al. Smoking cessation in women concerned about weight. Am J Public Health 1992;82:1238-43.

30 Spring B, Pagoto S, Pingitore R, Doran N, Schneider K, Hedeker D. Randomized controlled trial for behavioral smoking and weight control treatment: effect of concurrent versus sequential intervention. J Consult Clin Psychol 2004;72:785-96.

31 Nakamura M, Oshima A, Fujimoto Y, Maruyama N, Ishibashi T, Reeves KR. Efficacy and tolerability of varenicline, an alpha4beta2 nicotinic acetylcholine receptor partial agonist, in a 12-week, randomized, placebo-controlled, dose-response study with 40-week follow-up for smoking cessation in Japanese smokers. Clin Ther 2007;29:1040-56.

32 Tsai ST, Cho HJ, Cheng HS, Kim H, Hsueh KC, Billing CB, et al. Varenicline, a selective alpha4beta2 nicotinic acetylcholine receptor partial agonist, as a new therapy for smoking cessation: Asian experience. Clin Ther 2007;29:1027-39.

33 Wang C, Xiao D, Chan KP, Pothirat C, Garza D, Davies S. Varenicline for smoking cessation: a placebo-controlled, randomized study. Respirology 2009;14:384-92.

34 Klesges RC, Klesges LM, DeBon M, Shelton ML, Isbell TR, Klem ML. Effects of phenylpropanolamine on withdrawal symptoms. Psychopharmacology (Berl) 1995;119:85-91.

35 Marcus BH, Albrecht AE, King TK, Parisi AF, Pinto BM, Roberts M, et al. The efficacy of exercise as an aid for smoking cessation in women: a randomized controlled trial. Arch Intern Med 1999;159:1229-34

36 Spring B, Wurtman J, Wurtman R, el-Khoury A, Goldberg H, McDermott J, et al. Efficacies of dexfenfluramine and fluoxetine in preventing weight gain after smoking cessation. $A m$ J Clin Nutr 1995;62:1181-7.
37 Lerman C, Kaufmann V, Rukstalis M, Patterson F, Perkins K, Audrain-McGovern J, et al Individualizing nicotine replacement therapy for the treatment of tobacco dependence: randomized trial. Ann Intern Med 2004;140:426-33.

38 West R, Hajek P, Stead L, Stapleton J. Outcome criteria in smoking cessation trials: proposal for a common standard. Addiction 2005:100:299-303

39 Garvey AJ, Kinnunen T, Nordstrom BL, Utman CH, Doherty K, Rosner B, et al. Effects of nicotine gum dose by level of nicotine dependence. Nicotine Tob Res 2000;2:53-63.

40 Abelin T, Buehler A, Muller P, Vesanen K, Imhof PR. Controlled trial of transdermal nicotine patch in tobacco withdrawal. Lancet 1989;1:7-10.

41 Fiore MC, Kenford SL, Jorenby DE, Wetter DW, Smith SS, Baker TB. Two studies of the clinical effectiveness of the nicotine patch with different counseling treatments. Chest 1994;105:524-33.

42 Pack QR, Jorenby DE, Fiore MC, Jackson T, Weston P, Piper ME, et al. A comparison of the nicotine lozenge and nicotine gum: an effectiveness randomized controlled trial. WMJ 2008;107:237-43.

43 Piper ME, Federman EB, McCarthy DE, Bolt DM, Smith SS, Fiore MC, et al. Efficacy of bupropion alone and in combination with nicotine gum. Nicotine Tob Res 2007;9:947-54.

44 Rigotti NA, Thorndike AN, Regan S, McKool K, Pasternak RC, Chang Y, et al. Bupropion for smokers hospitalized with acute cardiovascular disease. Am J Med 2006;119:1080-7.

45 Toll BA, White M, Wu R, Meandzija B, Jatlow P, Makuch R, et al. Low-dose naltrexone augmentation of nicotine replacement for smoking cessation with reduced weight gain: a randomized trial. Drug Alcohol Depend 2010;111:200-6.

46 Ehrsam RE, Buhler A, Muller P, Mauli D, Schumacher PM, Howald H, et al. [Weaning of young smokers using a transdermal nicotine patch]. Schweiz Rundsch Med Prax 1991:80:145-50.

47 Uyar M, Filiz A, Bayram N, Elbek O, Herken H, Topcu A, et al. A randomized trial of smoking cessation. Medication versus motivation. Saudi Med J 2007;28:922-6.

48 Pomerleau CS, Kurth CL. Willingness of female smokers to tolerate postcessation weight gain. J Subst Abuse 1996;8:371-8.

49 Yeh HC, Duncan BB, Schmidt MI, Wang NY, Brancati FL. Smoking, smoking cessation, and risk for type 2 diabetes mellitus: a cohort study. Ann Intern Med 2010;152:10-7.

50 Hughes JR, Carpenter MJ, Naud S. Do point prevalence and prolonged abstinence measures produce similar results in smoking cessation studies? A systematic review. Nicotine Tob Res 2010;12:756-62.

51 Hall SM, Ginsberg D, Jones RT. Smoking cessation and weight gain. J Consult Clin Psychol 1986:54:342-6.

52 Aubin HJ, Berlin I, Smadja E, West R. Factors associated with higher body mass index, weight concern, and weight gain in a multinational cohort study of smokers intending to quit. Int J Environ Res Public Health 2009;6:943-57.

53 Thorner-Bantug E, Jaszyna-Gasior M, Schroeder JR, Collins CC, Moolchan ET. Weight gain, related concerns, and treatment outcomes among adolescent smokers enrolled in cessation treatment. J Nat/ Med Assoc 2009:101:1009-14.

54 Mokdad AH, Serdula MK, Dietz WH, Bowman BA, Marks JS, Koplan JP. The spread of the obesity epidemic in the United States, 1991-1998. JAMA 1999;282:1519-22.

55 O'Hara P, Connett JE, Lee WW, Nides M, Murray R, Wise R. Early and late weight gain following smoking cessation in the Lung Health Study. Am J Epidemiol 1998;148:821-30

56 Lycett D, Munafo M, Johnstone E, Murphy M, Aveyard P. Associations between weight change over 8 years and baseline body mass index in a cohort of continuing and quitting smokers. Addiction 2011:106:188-96.

57 Kadowaki T, Watanabe M, Okayama A, Hishida K, Okamura T, Miyamatsu N, et al. Continuation of smoking cessation and following weight change after intervention in a healthy population with high smoking prevalence. J Occup Health 2006;48:402-6.

58 Chen Y, Horne SL, Dosman JA. The influence of smoking cessation on body weight may be temporary. Am J Public Health 1993:83:1330-2.

59 Lycett D, Aveyard P. Munafo M, Johnstone M, Murphy M. What happened to their weight 8 years after nicotine patch treatment? [electronic rapid response to Yudkin $P$, Hey Yudkin K, Roberts Yudkin S, Welch S, Murphy M, Robert Walton. Abstinence from smoking eight years after participation in randomised controlled trial of nicotine patch]. BMJ 2009. www. bmj.com/rapid-response/2011/11/02/what-happened-their-weight-8-years-after-nicotinepatch-treatment.

60 Borrelli B, Spring B, Niaura R, Kristeller J, Ockene JK, Keuthen NJ. Weight suppression and weight rebound in ex-smokers treated with fluoxetine. J Consult Clin Psychol 1999;67:124-31.

61 Copeland AL, Martin PD, Geiselman PJ, Rash CJ, Kendzor DE. Smoking cessation for weight-concerned women: group vs individually tailored, dietary, and weight-contro follow-up sessions. Addict Behav 2006;31:115-27.

62 Pomerleau CS, Zucker AN, Stewart AJ. Characterizing concerns about post-cessation weight gain: results from a national survey of women smokers. Nicotine Tob Res 2001;3:51-60.

63 Meyers AW, Klesges RC, Winders SE, Ward KD, Peterson BA, Eck LH. Are weight concerns predictive of smoking cessation? A prospective analysis. J Consult Clin Psychol 1997;65:448-52.

64 Zhou X, Nonnemaker J, Sherrill B, Gilsenan AW, Coste F, West R. Attempts to quit smoking and relapse: factors associated with success or failure from the ATTEMPT cohor study. Addict Behav 2009;34:365-73.

65 Clark MM, Hurt RD, Croghan IT, Patten CA, Novotny P, Sloan JA, et al. The prevalence of weight concerns in a smoking abstinence clinical trial. Addict Behav 2006:31:1144-52.

66 Killen JD, Fortmann SP, Kraemer HC, Varady AN, Davis L, Newman B. Interactive effects of depression symptoms, nicotine dependence, and weight change on late smoking relapse. J Consult Clin Psychol 1996;64:1060-7.

67 Hutter H, Moshammer H, Neuberger M. Smoking cessation at the workplace: 1 year success of short seminars. Int Arch Occup Environ Health 2006;79:42-8. 
68 Cooper TV, Dundon M, Hoffman BM, Stoever CJ. General and smoking cessation related weight concerns in veterans. Addict Behav 2006;31:722-5.

69 Davey Smith G, Bracha Y, Svendsen KH, Neaton JD, Haffner SM, Kuller LH. Incidence of type 2 diabetes in the randomized multiple risk factor intervention trial. Ann Intern Med 2005;142:313-22.

70 Flegal KM, Troiano RP, Pamuk ER, Kuczmarski RJ, Campbell SM. The influence of smoking cessation on the prevalence of overweight in the United States. N Engl J Med 1995:333:1165-70.

71 Koster A, Leitzmann MF, Schatzkin A, Adams KF, van Eijk JT, Hollenbeck AR, et al. The combined relations of adiposity and smoking on mortality. Am J Clin Nutr 2008;88:1206-12.

72 Pednekar MS, Gupta PC, Hebert JR, Hakama M. Joint effects of tobacco use and body mass on all-cause mortality in Mumbai, India: results from a population-based cohort study. Am J Epidemiol 2008;167:330-40

73 Chinn S, Jarvis D, Melotti R, Luczynska C, Ackermann-Liebrich U, Anto JM, et al. Smoking cessation, lung function, and weight gain: a follow-up study. Lancet 2005;365:1629-35; discussion 1.

74 Aubin HJ, Bobak A, Britton JR, Oncken C, Billing CB Jr, Gong J, et al. Varenicline versus transdermal nicotine patch for smoking cessation: results from a randomised open-label trial. Thorax 2008;63:717-24.

75 Blondal T, Gudmundsson LJ, Tomasson K, Jonsdottir D, Hilmarsdottir H, Kristjansson F, et al. The effects of fluoxetine combined with nicotine inhalers in smoking cessation-a randomized trial. Addiction 1999;94:1007-15.

76 Bohadana A, Nilsson F, Rasmussen T, Martinet Y. Nicotine inhaler and nicotine patch as a combination therapy for smoking cessation: a randomized, double-blind, placebo-controlled trial. Arch Intern Med 2000;160:3128-34.

77 Dale LC, Hurt RD, Offord KP, Lawson GM, Croghan IT, Schroeder DR. High-dose nicotine patch therapy. Percentage of replacement and smoking cessation. JAMA 1995;274:1353-8.

78 Gonzales D, Rennard SI, Nides M, Oncken C, Azoulay S, Billing CB, et al. Varenicline, a gamma4beta2 nicotinic acetylcholine receptor partial agonist, vs sustained-release bupropion and placebo for smoking cessation. JAMA 2006;296:47-55.

79 Gourlay SG, Forbes A, Marriner T, Pethica D, McNeil JJ. Double blind trial of repeated treatment with transdermal nicotine for relapsed smokers. BMJ 1995;311:363-6.

80 Gross J, Johnson J, Sigler L, Stitzer ML. Dose effects of nicotine gum. Addict Behav 1995;20:371-81.

81 Hjalmarson Al. Effect of nicotine chewing gum in smoking cessation. A randomized, placebo-controlled, double-blind study. JAMA 1984;252:2835-8.

82 Hjalmarson A, Franzon M, Westin A, Wiklund O. Effect of nicotine nasal spray on smoking cessation. A randomized, placebo-controlled, double-blind study. Arch Intern Med 1994:154:2567-72.

83 Hjalmarson A, Nilsson F, Sjostrom L, Wiklund O. The nicotine inhaler in smoking cessation. Arch Intern Med 1997;157:1721-8.

84 Hurt RD, Sachs DP, Glover ED, Offord KP, Johnston JA, Dale LC, et al. A comparison of sustained-release bupropion and placebo for smoking cessation. N Engl J Med 1997;337:1195-202.

85 Jorenby DE, Hays JT, Rigotti NA, Azoulay S, Watsky EJ, Williams KE, et al. Efficacy of varenicline, an alpha4beta2 nicotinic acetylcholine receptor partial agonist, vs placebo or sustained-release bupropion for smoking cessation. JAMA 2006;296:56-63.

86 Klesges RC, Klesges LM, Meyers AW, Klem ML, Isbell T. The effects of phenylpropanolamine on dietary intake, physical activity, and body weight after smoking cessation. Clin Pharmacol Ther 1990:47:747-54.

87 Niaura R, Spring B, Borrelli B, Hedeker D, Goldstein MG, Keuthen N, et al. Multicenter trial of fluoxetine as an adjunct to behavioral smoking cessation treatment. J Consult Clin Psychol 2002;70:887-96

88 Niaura R, Hays JT, Jorenby DE, Leone FT, Pappas JE, Reeves KR, et al. The efficacy and safety of varenicline for smoking cessation using a flexible dosing strategy in adult smokers: a randomized controlled trial. Curr Med Res Opin 2008;24:1931-41.

89 Nides M, Oncken C, Gonzales D, Rennard S, Watsky EJ, Anziano R, et al. Smoking cessation with varenicline, a selective alpha4beta2 nicotinic receptor partial agonist. Arch Intern Med 2006;166:1561-8.
90 Oncken C, Gonzales D, Nides M, Rennard S, Watsky E, Billing CB, et al. Efficacy and safety of the novel selective nicotinic acetylcholine receptor partial agonist, varenicline, for smoking cessation. Arch Intern Med 2006;166:1571-7.

91 Puska P, Korhonen HJ, Vartiainen E, Urjanheimo EL, Gustavsson G, Westin A. Combined use of nicotine patch and gum compared with gum alone in smoking cessation: a clinical trial in North Karelia. Tob Control 1995;4:231-5.

92 Richmond RL, Harris K, de Almeida Neto A. The transdermal nicotine patch: results of a randomised placebo-controlled trial. Med J Aust 1994:161:130-5.

93 Rigotti NA, Pipe AL, Benowitz NL, Arteaga C, Garza D, Tonstad S. Efficacy and safety of varenicline for smoking cessation in patients with cardiovascular disease: a randomized trial. Circulation 2010;121:221-9.

94 Sachs DP, Sawe U, Leischow SJ. Effectiveness of a 16-hour transdermal nicotine patch in a medical practice setting, without intensive group counseling. Arch Intern Med 1993:153:1881-90.

95 Saules KK, Schuh LM, Arfken CL, Reed K, Kilbey MM, Schuster CR. Double-blind placebo-controlled trial of fluoxetine in smoking cessation treatment including nicotine patch and cognitive-behavioral group therapy. Am J Addict 2004;13:438-46.

96 Shiffman S, Dresler CM, Hajek P, Gilburt SJ, Targett DA, Strahs KR. Efficacy of a nicotine lozenge for smoking cessation. Arch Intern Med 2002;162:1267-76.

97 Simon JA, Duncan C, Carmody TP, Hudes ES. Bupropion for smoking cessation: a randomized trial. Arch Intern Med 2004;164:1797-803.

98 Simon JA, Duncan C, Huggins J, Solkowitz S, Carmody TP. Sustained-release bupropion for hospital-based smoking cessation: a randomized trial. Nicotine Tob Res 2009;11:663-9.

99 Stapleton JA, Russell MA, Feyerabend C, Wiseman SM, Gustavsson G, Sawe U, et al. Dose effects and predictors of outcome in a randomized trial of transdermal nicotine patches in general practice. Addiction 1995;90:31-42.

100 Sutherland G, Stapleton JA, Russell MA, Jarvis MJ, Hajek P, Belcher M, et al. Randomised controlled trial of nasal nicotine spray in smoking cessation. Lancet 1992;340:324-9.

101 Tashkin DP, Rennard S, Hays JT, Ma W, Lawrence D, Lee TC. Effects of varenicline on smoking cessation in patients with mild to moderate COPD: a randomized controlled trial. Chest 2011;139:591-9.

102 Tonnesen P, Norregaard J, Simonsen K, Sawe U. A double-blind trial of a 16-hour transdermal nicotine patch in smoking cessation. N Engl J Med 1991;325:311-5.

103 Tonnesen P, Norregaard J, Mikkelsen K, Jorgensen S, Nilsson F. A double-blind trial of a nicotine inhaler for smoking cessation. JAMA 1993;269:1268-71.

104 Tonnesen P, Paoletti P, Gustavsson G, Russell MA, Saracci R, Gulsvik A, et al. Higher dosage nicotine patches increase one-year smoking cessation rates: results from the European CEASE trial. Collaborative European Anti-Smoking Evaluation. European Respiratory Society. Eur Respir J 1999;13:238-46.

105 Tonstad S, Tonnesen P, Hajek P, Williams KE, Billing CB, Reeves KR. Effect of maintenance therapy with varenicline on smoking cessation. JAMA 2006;296:64-71.

106 Transdermal Nicotine Study Group. Transdermal nicotine for smoking cessation. Six-month results from two multicenter controlled clinical trials. JAMA 1991;266:3133-8.

107 Wallstrom M, Nilsson F, Hirsch JM. A randomized, double-blind, placebo-controlled clinical evaluation of a nicotine sublingual tablet in smoking cessation. Addiction 2000:95:1161-71.

108 Zellweger JP, Boelcskei PL, Carrozzi L, Sepper R, Sweet R, Hider AZ. Bupropion SR vs placebo for smoking cessation in health care professionals. Am J Health Behav 2005;29:240-9.

Accepted: 17 May 2012

\section{Cite this as: BMJ 2012:345:e4439}

This is an open-access article distributed under the terms of the Creative Commons Attribution Non-commercial License, which permits use, distribution, and reproduction in any medium, provided the original work is properly cited, the use is non commercial and is otherwise in compliance with the license. See: http://creativecommons.org/licenses/bync/2.0/ and http://creativecommons.org/licenses/by-nc/2.0/legalcode. 


\section{Tables}

\section{Table 1| Application of Altman's criteria for judging the quality of studies on outcome}

\begin{tabular}{lll} 
Criterion & \multicolumn{1}{c}{ Altman criteria } & \multicolumn{1}{c}{ How applied in this review } \\
Sample of patients & $\begin{array}{l}\text { Inclusion criteria defined, sample selection explained, adequate } \\
\text { description of diagnostic criteria, clinical and demographic } \\
\text { characteristics fully described, representative, assembled at } \\
\text { common (usually early) point in course of disease, complete (all } \\
\text { eligible patients included) }\end{array}$ & $\begin{array}{l}\text { All cohorts included smokers wanting to quit, assembled before } \\
\text { quit day and with time measured from quit day. Population } \\
\text { categorised by type of abstinence measure (that is, prolonged or } \\
\text { continuous, point prevalence and biochemically confirmed or not). }\end{array}$ \\
\hline Follow-up of patients & Sufficiently long & Followed at 1, 2, 3, 6, and 12 months \\
\hline Outcome & $\begin{array}{l}\text { Objective, unbiased (for example, assessment blinded to } \\
\text { prognostic information), fully defined, appropriate, known for all } \\
\text { or high proportion of patients }\end{array}$ & $\begin{array}{l}\text { Self reported weight, measured weight, presumed measured, and } \\
\text { unclear }\end{array}$ \\
\hline Analysis & $\begin{array}{l}\text { Continuous predictor variable analysed appropriately, statistical } \\
\text { adjustment for all important prognostic factors }\end{array}$ & $\begin{array}{l}\text { Not applicable. The aim of the study was not to assess the effect } \\
\text { of a particular prognostic factor but to record the outcome in all } \\
\text { who were abstinent }\end{array}$ \\
\hline $\begin{array}{l}\text { Treatment subsequent to } \\
\text { inclusion in cohort }\end{array}$ & Fully described, treatment standardised or randomised & $\begin{array}{l}\text { Recorded pharmacological treatment received or no active } \\
\text { treatment to prevent weight gain }\end{array}$ \\
\hline
\end{tabular}




\begin{tabular}{|c|c|c|c|c|c|c|c|c|c|c|c|}
\hline Trial & $\begin{array}{c}\text { Aim of } \\
\text { treatment }\end{array}$ & $\begin{array}{l}\text { Weight } \\
\text { change } \\
\text { follow-up } \\
\text { points }\end{array}$ & Region & Abstinence & $\begin{array}{l}\text { Biochemical } \\
\text { validation }\end{array}$ & $\begin{array}{c}\text { Weight } \\
\text { measurement }\end{array}$ & Treatment ${ }^{\star}$ & $\begin{array}{c}\text { Patients } \\
\text { (no) at } \\
\text { baseline }\end{array}$ & $\begin{array}{l}\text { Women } \\
\text { at } \\
\text { baseline } \\
(\%)\end{array}$ & $\begin{array}{c}\text { Mean } \\
\text { age at } \\
\text { baseline } \\
\text { (years) }\end{array}$ & $\begin{array}{l}\text { Mean smoking } \\
\text { intake at } \\
\text { baseline } \\
\text { (cigarettes/day) }\end{array}$ \\
\hline \multirow{2}{*}{$\begin{array}{l}\text { Abelin et al } \\
1989^{40}\end{array}$} & \multirow[t]{2}{*}{ SC } & \multirow[t]{2}{*}{ Month 3} & \multirow[t]{2}{*}{ Europe } & \multirow[t]{2}{*}{ PA } & \multirow[t]{2}{*}{ Yes } & \multirow[t]{2}{*}{ NR } & NRT & 99 & 42 & $41(10)$ & $28(10)$ \\
\hline & & & & & & & Control & 100 & 72 & $43(11)$ & $27(11)$ \\
\hline \multirow{2}{*}{$\begin{array}{l}\text { Aubin et al } \\
2008^{74}\end{array}$} & \multirow[t]{2}{*}{$\mathrm{SC}$} & \multirow[t]{2}{*}{ Month 3} & \multirow[t]{2}{*}{ Europe } & \multirow[t]{2}{*}{ PA } & \multirow[t]{2}{*}{ Yes } & \multirow{2}{*}{$\begin{array}{l}\text { Clinic } \\
\text { weighed }\end{array}$} & Varenicline & 376 & 52 & $43(11)$ & 23 \\
\hline & & & & & & & NRT & 370 & 50 & $43(12)$ & 22 \\
\hline $\begin{array}{l}\text { Blondal et al } \\
1999^{75}\end{array}$ & SC & $\begin{array}{l}\text { Months 6, } \\
12\end{array}$ & Europe & $\mathrm{CA}$ & Yes & NR & NRT & 240 & 71 & 42 & $29(1)$ \\
\hline $\begin{array}{l}\text { Bohadana et } \\
\text { al } 2000^{76}\end{array}$ & SC & $\begin{array}{l}\text { Months 6, } \\
12\end{array}$ & Europe & PA & Yes & NR & NRT & 400 & 51 & $37(9)$ & $25(10)$ \\
\hline \multirow{2}{*}{$\begin{array}{l}\text { Cooper et al } \\
2005^{23}\end{array}$} & \multirow{2}{*}{$\begin{array}{l}\text { SC and } \\
\text { PCWGP }\end{array}$} & \multirow{2}{*}{$\begin{array}{l}\text { Months } \\
2,6,12\end{array}$} & \multirow[t]{2}{*}{ USA } & \multirow[t]{2}{*}{ PP } & \multirow[t]{2}{*}{ Yes } & \multirow{2}{*}{$\begin{array}{l}\text { Clinic } \\
\text { weighed }\end{array}$} & NRT & 148 & 100 & $38(11)$ & $23(8)$ \\
\hline & & & & & & & Control & 148 & 100 & $39(10)$ & $23(8)$ \\
\hline $\begin{array}{l}\text { Dale et al } \\
1995^{77}\end{array}$ & SC & $\begin{array}{l}\text { Months 2, } \\
12\end{array}$ & USA & $\mathrm{CA}$ & Yes & Clinic weighed & NRT & 52 & 56 & $48(12) \dagger$ & $26(11) \dagger$ \\
\hline \multirow{2}{*}{$\begin{array}{l}\text { Ehrsam et al } \\
1991^{46}\end{array}$} & SC & Month 2 & Europe & $\mathrm{NR}$ & NR & Clinic & NRT & 56 & NR & NR & $22(7)$ \\
\hline & & & & & & weighed & Control & 56 & NR & $N R$ & $24(7)$ \\
\hline Fiore et al & SC & Month 2 & USA & PP & Yes & NR & NRT & 44 & 57 & $43(10)$ & $28(8)$ \\
\hline $1994 a^{4}$ & & & & & & & Control & 43 & 56 & $43(9)$ & $30(10)$ \\
\hline Fiore et al & sc & Month 2 & USA & PP & Yes & NR & NRT & 57 & 68 & $43(9)$ & $30(10)$ \\
\hline & & & & & & & Control & 55 & 67 & $44(11)$ & $31(10)$ \\
\hline Garvey et al & SC & Month 1 & USA & PA & Yes & Clinic & NRT & 405 & 49 & $41(12)$ & $24(11)$ \\
\hline & & & & & & & Control & 203 & 51 & $40(12)$ & $23(11)$ \\
\hline Gonzales et & SC & Month 3 & USA & PA & Yes & Clinic & Varenicline & 352 & 40 & $43(12)$ & $21(10)$ \\
\hline al $2006^{88}$ & & & & & & weighed & Bupropion & 329 & 42 & $42(12)$ & $21(9)$ \\
\hline & & & & & & & Control & 344 & 45 & $43(12)$ & $22(10)$ \\
\hline Gourlay et al & SC & Month 3 & Australia & $\mathrm{CA}$ & Yes & $N R$ & NRT & 315 & 58 & $41(11)$ & $28(10)$ \\
\hline $1995^{9}$ & & & & & & & Control & 314 & 57 & $42(10)$ & $27(9)$ \\
\hline Gross et al & sc & Month 3 & USA & $\mathrm{CA}$ & Yes & Clinic & NRT & 132 & 51 & $42(10)$ & $33(11)$ \\
\hline & & & & & & weighed & Control & 46 & & & \\
\hline $\begin{array}{l}\text { Hall et al } \\
1992^{24}\end{array}$ & $\begin{array}{l}\text { SC and } \\
\text { PCWGP }\end{array}$ & $\begin{array}{l}\text { Months 2, } \\
12\end{array}$ & USA & PP & Yes & Clinic weighed & Control & 54 & 27 & $39(9)$ & $32(12)$ \\
\hline Hjalmarson & SC & Month 6 & Europe & $\mathrm{CA}$ & Yes & NR & NRT & 106 & 46 & $43(11)$ & $24(10)$ \\
\hline et al $1984^{81}$ & & & & & & & Control & 100 & 56 & $41(14)$ & $24(10)$ \\
\hline Hjalmarson & SC & Month 12 & Europe & $\mathrm{CA}$ & Yes & Clinic & NRT & 125 & 42 & $45(12)$ & $21(6)$ \\
\hline et al $1994^{\circ 2}$ & & & & & & weighed & Control & 123 & 57 & 45 (12) & $22(8)$ \\
\hline Hjalmarson & $\mathrm{SC}$ & Months & Europe & $\mathrm{CA}$ & Yes & NR & $\underline{\mathrm{NRT}}$ & 123 & 38 & $48(11)$ & $22(8)$ \\
\hline et al $1997^{83}$ & & $\begin{array}{l}1,2,3,6, \\
12\end{array}$ & & & & & Control & 124 & 64 & $47(10)$ & $21(8)$ \\
\hline Hurt et al & SC & Months & USA & $\mathrm{CA}$ & Yes & $N R$ & Bupropion & 156 & 51 & $45(12)$ & $27(11)$ \\
\hline $1997^{\circ 4}$ & & $2,6,12$ & & & & & Control & 153 & 55 & $43(11)$ & 27 (9) \\
\hline Jorenby et al & $\mathrm{SC}$ & Month 3 & USA & $\mathrm{CA}$ & Yes & NR & Varenicline & 344 & 45 & $45(11)$ & $23(10)$ \\
\hline & & & & & & & Bupropion & 342 & 40 & $43(12)$ & $22(9)$ \\
\hline & & & & & & & Control & 341 & 41 & $42(12)$ & $22(9)$ \\
\hline $\begin{array}{l}\text { Klesges et al } \\
1990^{86}\end{array}$ & $\begin{array}{l}\text { SC and } \\
\text { PCWGP }\end{array}$ & Month 1 & USA & $\mathrm{CA}$ & Yes & NR & Control & 20 & 100 & $28(8) \dagger$ & $22(10) \dagger$ \\
\hline $\begin{array}{l}\text { Klesges et al } \\
1995^{34}\end{array}$ & $\begin{array}{l}\text { SC and } \\
\text { PCWGP }\end{array}$ & Month 1 & USA & $\mathrm{CA}$ & Yes & Clinic weighed & Control & 55 & NR & NR & NR \\
\hline $\begin{array}{l}\text { Lerman et al } \\
2004^{37}\end{array}$ & SC & $\begin{array}{l}\text { Months 2, } \\
6\end{array}$ & USA & CA & No & Self reported & NRT & 299 & 54 & $46(11)$ & $21(11)$ \\
\hline Levine et al & SC and & Months & USA & PA & Yes & Clinic & Bupropion & 89 & 100 & $41(11)$ & $20(7)$ \\
\hline $2010^{25}$ & & $3,6,12$ & & & & weighed & Control & 67 & 100 & $42(10)$ & $22(9)$ \\
\hline
\end{tabular}


Table 2 (continued)

\begin{tabular}{|c|c|c|c|c|c|c|c|c|c|c|c|}
\hline Trial & $\begin{array}{c}\text { Aim of } \\
\text { treatment }\end{array}$ & $\begin{array}{l}\text { Weight } \\
\text { change } \\
\text { follow-up } \\
\text { points }\end{array}$ & Region & Abstinence & $\begin{array}{l}\text { Biochemical } \\
\text { validation }\end{array}$ & $\begin{array}{c}\text { Weight } \\
\text { measurement }\end{array}$ & Treatment $^{\star}$ & $\begin{array}{c}\text { Patients } \\
\text { (no) at } \\
\text { baseline }\end{array}$ & $\begin{array}{c}\text { Women } \\
\text { at } \\
\text { baseline } \\
(\%)\end{array}$ & $\begin{array}{c}\text { Mean } \\
\text { age at } \\
\text { baseline } \\
\text { (years) }\end{array}$ & $\begin{array}{c}\text { Mean smoking } \\
\text { intake at } \\
\text { baseline } \\
\text { (cigarettes/day) }\end{array}$ \\
\hline $\begin{array}{l}\text { Marcus et al } \\
1999^{35}\end{array}$ & SC & $\begin{array}{l}\text { Months 3, } \\
12\end{array}$ & USA & $\mathrm{CA}$ & Yes & Clinic weighed & Control & 147 & 100 & $40(9)$ & $22(9)$ \\
\hline \multirow{2}{*}{$\begin{array}{l}\text { Nakamura et } \\
\text { al } 2007^{31}\end{array}$} & \multirow{2}{*}{ SC } & \multirow[t]{2}{*}{ Month 3} & \multirow[t]{2}{*}{ Asia } & \multirow[t]{2}{*}{ PA } & \multirow[t]{2}{*}{ Yes } & \multirow{2}{*}{$\begin{array}{l}\text { Clinic } \\
\text { weighed }\end{array}$} & Varenicline & 130 & 21 & $40(12)$ & $24(10)$ \\
\hline & & & & & & & Control & 129 & 24 & $40(12)$ & $23(9)$ \\
\hline $\begin{array}{l}\text { Niaura et al } \\
2002^{87}\end{array}$ & $\mathrm{SC}$ & Month 2 & USA & $\mathrm{CA}$ & Yes & Clinic weighed & Control & 333 & 61 & $41(10)$ & $27(11)$ \\
\hline \multirow{2}{*}{$\begin{array}{l}\text { Niaura et al } \\
2008^{88}\end{array}$} & \multirow[t]{2}{*}{ SC } & \multirow[t]{2}{*}{ Month 3} & \multirow[t]{2}{*}{ USA } & \multirow[t]{2}{*}{ PA } & \multirow[t]{2}{*}{ Yes } & \multirow{2}{*}{$\begin{array}{l}\text { Clinic } \\
\text { weighed }\end{array}$} & Varenicline & 157 & 50 & $42(11)$ & 22 \\
\hline & & & & & & & Control & 155 & 47 & $42(12)$ & 22 \\
\hline \multirow{2}{*}{$\begin{array}{l}\text { Nides et al } \\
2006^{89}\end{array}$} & \multirow[t]{2}{*}{ SC } & \multirow[t]{2}{*}{ Month 2} & \multirow[t]{2}{*}{ USA } & \multirow[t]{2}{*}{ PA } & \multirow[t]{2}{*}{ Yes } & \multirow{2}{*}{$\begin{array}{l}\text { Clinic } \\
\text { weighed }\end{array}$} & Varenicline & 127 & 50 & $42(11)$ & $19(7)$ \\
\hline & & & & & & & Bupropion & 128 & 55 & $41(11)$ & $20(7)$ \\
\hline $\begin{array}{l}\text { Norregaard et } \\
\text { al } 1996^{26}\end{array}$ & $\begin{array}{l}\text { SC and } \\
\text { PCWGP }\end{array}$ & $\begin{array}{l}\text { Months 2, } \\
3,6,12\end{array}$ & Europe & $\mathrm{CA}$ & Yes & Clinic weighed & Control & 73 & 65 & 39 & 20 \\
\hline $\begin{array}{l}\text { O'Malley et al } \\
2006^{27}\end{array}$ & $\begin{array}{l}\text { SC and } \\
\text { PCWGP }\end{array}$ & Month 2 & USA & $\mathrm{CA}$ & Yes & Clinic weighed & Control & 93 & 46 & $46(11)$ & $27(11)$ \\
\hline \multirow{2}{*}{$\begin{array}{l}\text { Oncken et al } \\
2006^{90}\end{array}$} & \multirow{2}{*}{$\mathrm{SC}$} & \multirow[t]{2}{*}{ Month 2} & USA & PA & Yes & Clinic & Varenicline & 259 & 51 & $43(10)$ & $21(9)$ \\
\hline & & & & & & weighed & Control & 129 & 48 & $43(9)$ & $20(7)$ \\
\hline $\begin{array}{l}\text { Pack et al } \\
2008^{42}\end{array}$ & SC & $\begin{array}{l}\text { Month 2, } \\
6,12\end{array}$ & USA & PP & Yes & NR & NRT & 408 & 56 & $43(12)$ & $23(10)$ \\
\hline $\begin{array}{l}\text { Parsons et al } \\
2009^{21}\end{array}$ & $\begin{array}{l}\text { SC and } \\
\text { PCWGP }\end{array}$ & $\begin{array}{l}\text { Months 1, } \\
6\end{array}$ & Europe & PA & Yes & Clinic weighed & Control & 35 & 71 & $49(13)$ & $22(12)$ \\
\hline $\begin{array}{l}\text { Perkins et al } \\
2001^{28}\end{array}$ & $\begin{array}{l}\text { SC and } \\
\text { PCWGP }\end{array}$ & $\begin{array}{l}\text { Months 1, } \\
6,12\end{array}$ & USA & $\mathrm{CA}$ & Yes & Clinic weighed & Control & 75 & 100 & $46(10)$ & $26(5)$ \\
\hline Piper et al & SC & Month 2 & USA & PP & Yes & Clinic & Bupropion & 224 & 60 & $42(11)$ & $23(11)$ \\
\hline $1992^{29}$ & PCWGP & $1,6,12$ & & & & weighed & Control & 103 & 100 & $42(9)$ & $26(12)$ \\
\hline $\begin{array}{l}\text { Puska et al } \\
1995^{91}\end{array}$ & SC & $\begin{array}{l}\text { Months } 6 \text {, } \\
12\end{array}$ & Europe & PA & Yes & NR & NRT & 300 & 43 & $40(9)$ & $21(9)$ \\
\hline Richmond et & SC & Months & Australia & PA & Yes & NR & NRT & 153 & NR & NR & NR \\
\hline & & $3,6,12$ & & & & & Control & 152 & NR & NR & NR \\
\hline Rigotti et al & SC & Months & USA & PP & Yes & NR & Bupropion & 124 & 31 & $57(10)$ & $23(14)$ \\
\hline & & & & & & & Control & 124 & 31 & $55(10)$ & $21(11)$ \\
\hline Rigotti et al & SC & Months & Worldwide & $\mathrm{CA}$ & Yes & Clinic & Varenicline & 355 & 25 & $57(9)$ & 22 \\
\hline $2010^{93}$ & & 3,12 & & & & weighed & Control & 359 & 18 & $56(8)$ & 23 \\
\hline Sachs et al & SC & Month 6 & USA & $\mathrm{CA}$ & Yes & NR & $\underline{N R T}$ & 113 & 59 & $48(11)$ & $27(9)$ \\
\hline & & & & & & & Control & 107 & 59 & $48(11)$ & $29(11)$ \\
\hline $\begin{array}{l}\text { Saules et al } \\
2004^{95}\end{array}$ & SC & Month 6 & USA & $\mathrm{CA}$ & Yes & NR & NRT & 48 & 52 & 41 & $N R$ \\
\hline Shiffman et & SC & Months & USA Europe & $\mathrm{CA}$ & Yes & Clinic & NRT & 459 & 57 & $41(12)$ & $18(8)$ \\
\hline al $2002 a^{96}$ & & $3,6,12$ & & & & weighed & Control & 458 & 60 & $40(12)$ & $17(9)$ \\
\hline Shiffman et & SC & Months & USA-Europe & $\mathrm{CA}$ & Yes & Clinic & NRT & 450 & 57 & $44(12)$ & $26(11)$ \\
\hline al $2002 b^{96}$ & & $3,6,12$ & & & & & Control & 451 & 53 & $45(12)$ & $27(10)$ \\
\hline $\begin{array}{l}\text { Simon et al } \\
2004^{97}\end{array}$ & SC & Month 12 & USA & $\mathrm{CA}$ & Yes & Unclear & NRT & 123 & 16 & $49(11)$ & $23(11)$ \\
\hline Simon et al & SC & Month 6, & USA & $\mathrm{CA}$ & Yes & NR & Bupropion & 42 & 7 & $55(8)$ & $16(11)$ \\
\hline $2009^{98}$ & & 12 & & & & & Control & 43 & 0 & $57(7)$ & $16(9)$ \\
\hline $\begin{array}{l}\text { Spring et al } \\
1995^{36}\end{array}$ & $\begin{array}{l}\text { SC and } \\
\text { PCWGP }\end{array}$ & Month 3 & USA & PA & Yes & Clinic weighed & Control & 48 & 100 & $41(11)$ & $27(12)$ \\
\hline
\end{tabular}


Table 2 (continued)

\begin{tabular}{|c|c|c|c|c|c|c|c|c|c|c|c|}
\hline Trial & $\begin{array}{c}\text { Aim of } \\
\text { treatment }\end{array}$ & $\begin{array}{c}\text { Weight } \\
\text { change } \\
\text { follow-up } \\
\text { points }\end{array}$ & Region & Abstinence & $\begin{array}{l}\text { Biochemical } \\
\text { validation }\end{array}$ & $\begin{array}{c}\text { Weight } \\
\text { measurement }\end{array}$ & Treatment $^{\star}$ & $\begin{array}{l}\text { Patients } \\
\text { (no) at } \\
\text { baseline }\end{array}$ & $\begin{array}{l}\text { Women } \\
\text { at } \\
\text { baseline } \\
(\%)\end{array}$ & $\begin{array}{c}\text { Mean } \\
\text { age at } \\
\text { baseline } \\
\text { (years) }\end{array}$ & $\begin{array}{c}\text { Mean smoking } \\
\text { intake at } \\
\text { baseline } \\
\text { (cigarettes/day) }\end{array}$ \\
\hline $\begin{array}{l}\text { Spring et al } \\
2004^{30}\end{array}$ & $\begin{array}{l}\text { SC and } \\
\text { PCWGP }\end{array}$ & $\begin{array}{l}\text { Months 3, } \\
6\end{array}$ & USA & PA & Yes & Clinic weighed & Control & 107 & 100 & $43(11)$ & $20(9)$ \\
\hline \multirow{2}{*}{$\begin{array}{l}\text { Stapleton et } \\
\text { al } 1995^{99}\end{array}$} & \multirow[t]{2}{*}{ sc } & \multirow{2}{*}{$\begin{array}{l}\text { Months } \\
3,12\end{array}$} & \multirow[t]{2}{*}{ Europe } & \multirow[t]{2}{*}{$\mathrm{CA}$} & \multirow[t]{2}{*}{ Yes } & \multirow[t]{2}{*}{ NR } & NRT & 800 & 58 & $40(10)$ & $24(7)$ \\
\hline & & & & & & & Control & 400 & 55 & $42(10)$ & $24(8)$ \\
\hline \multirow{2}{*}{$\begin{array}{l}\text { Sutherland } \\
\text { et al } 1992^{100}\end{array}$} & \multirow[t]{2}{*}{ SC } & \multirow[t]{2}{*}{ Month 12} & \multirow[t]{2}{*}{ Europe } & \multirow[t]{2}{*}{ PA } & \multirow[t]{2}{*}{ Yes } & \multirow{2}{*}{$\begin{array}{l}\text { Clinic } \\
\text { weighed }\end{array}$} & NRT & 116 & 63 & $39(9)$ & $25(10)$ \\
\hline & & & & & & & Control & 111 & 66 & $40(10)$ & $27(10)$ \\
\hline \multirow{2}{*}{$\begin{array}{l}\text { Tashkin et al } \\
2011^{101}\end{array}$} & \multirow[t]{2}{*}{ SC } & \multirow{2}{*}{$\begin{array}{l}\text { Months } \\
3,12\end{array}$} & \multirow[t]{2}{*}{ USA-Europe } & \multirow[t]{2}{*}{ PA } & \multirow[t]{2}{*}{ Yes } & \multirow[t]{2}{*}{ NR } & Varenicline & 248 & 37 & $57(9)$ & $25(11)$ \\
\hline & & & & & & & Control & 251 & 38 & $57(9)$ & 24 \\
\hline $\begin{array}{l}\text { Toll et al } \\
2010^{45}\end{array}$ & $\begin{array}{l}\text { SC and } \\
\text { PCWGP }\end{array}$ & $\begin{array}{l}\text { Months } 1 \text {, } \\
6\end{array}$ & USA & PP & Yes & Clinic weighed & NRT & 85 & 72 & $46(11)$ & $22(9)$ \\
\hline \multirow{2}{*}{$\begin{array}{l}\text { Tonnesen et } \\
\text { al } 1991^{102}\end{array}$} & \multirow[t]{2}{*}{$\mathrm{SC}$} & \multirow{2}{*}{$\begin{array}{l}\text { Months } \\
3,12\end{array}$} & \multirow[t]{2}{*}{ Europe } & \multirow[t]{2}{*}{ PA } & \multirow[t]{2}{*}{ Yes } & \multirow[t]{2}{*}{ NR } & NRT & 145 & 69 & 45 & 21 \\
\hline & & & & & & & Control & 144 & 70 & 45 & 22 \\
\hline \multirow{2}{*}{$\begin{array}{l}\text { Tonnesen et } \\
\text { al } 1993^{103}\end{array}$} & SC & Months & Europe & PA & Yes & NR & NRT & 145 & 63 & $39(12)$ & $20(6)$ \\
\hline & & 3,12 & & & & & Control & 141 & 60 & $39(14)$ & $20(7)$ \\
\hline Tonnesen et & SC & Months & Europe & $\mathrm{CA}$ & Yes & NR & NRT & 2861 & 51 & $41(10)$ & $27(10)$ \\
\hline & & $2,6,12$ & & & & & Control & 714 & 48 & $41(10)$ & $27(10)$ \\
\hline $\begin{array}{l}\text { Tonstad et al } \\
2006^{105}\end{array}$ & SC & Month 6 & USA-Canada-Europe & $\mathrm{CA}$ & Yes & Clinic weighed & Varenicline & 1927 & 51 & $44(11)$ & $22(8)$ \\
\hline Transdermal & $\mathrm{SC}$ & Month 2 & USA & $\mathrm{CA}$ & Yes & NR & NRT & 664 & 70 & $42(10)$ & $31(10)$ \\
\hline $\begin{array}{l}\text { Nicotine } \\
\text { Study Group } \\
1991^{106}\end{array}$ & & & & & & & Control & 271 & 60 & $43(10)$ & $31(11)$ \\
\hline Tsai et al & SC & Month 3 & Asia & PA & Yes & Clinic & Varenicline & 126 & 19 & $40(9)$ & 23 \\
\hline $2007^{32}$ & & & & & & weighed & Control & 124 & 7 & $41(11)$ & 23 \\
\hline Uyar et al & SC & Month 6 & Europe & $\mathrm{CA}$ & Yes & Self-reported & Bupropion & 50 & 12 & $36(11)$ & NR \\
\hline & & & & & & & NRT & 50 & 20 & $36(13)$ & NR \\
\hline & & & & & & & Control & 31 & 30 & $36(11)$ & NR \\
\hline Wallstrom et & SC & Month 12 & Europe & $\mathrm{CA}$ & Yes & $N R$ & NRT & 123 & 63 & $45(12)$ & $18(5)$ \\
\hline al $2000^{\circ}$ & & & & & & & Control & 124 & 59 & $45(11)$ & $21(7)$ \\
\hline Wang et al & SC & Months & Asia & PA & Yes & Clinic & Varenicline & 165 & 4 & 39 & 20 \\
\hline $2009^{33}$ & & 3,12 & & & & weighed & Control & 168 & 3 & 39 & 21 \\
\hline Zellweger et & SC & Months & Europe & PA & Yes & NR & Bupropion & 517 & 64 & $40(9)$ & $22(8)$ \\
\hline al $2005^{10}$ & & 2,12 & & & & & Control & 170 & 64 & $40(9)$ & $24(9)$ \\
\hline
\end{tabular}

$\mathrm{SC}=$ smoking cessation; $\mathrm{PCWGP}=$ postcessation weight gain; $\mathrm{NRT}=$ nicotine replacement therapy; $\mathrm{NR}=$ not reported; $\mathrm{PA}=$ prolonged abstinence; $\mathrm{CA}=$ continuous abstinence; $\mathrm{PP}=$ point prevalence abstinence. For the Shiffman studies, smokers were stratified and received two different treatments on the basis of nicotine dependence level (separated in "a" and "b" groups). For the Fiore studies, "a" and "b" refer to two separate studies reported in the same article.

${ }^{*}$ Control=data taken from placebo arms of pharmacotherapy trials and control arms of behavioural interventions. Only included if participants did not receive any intervention that could have affected weight (for example, nicotinic replacement therapy, exercise, dietary advice).

tWhole study population analysed. 


\begin{tabular}{|c|c|c|c|c|c|}
\hline Time after target quit day & $\begin{array}{c}\text { Mean }(95 \% \mathrm{Cl}) \text { change in weight } \\
(\mathrm{kg})^{\star}\end{array}$ & $\begin{array}{l}\text { Weighted mean } \\
\text { standard deviation† }\end{array}$ & $I^{2}(\%)$ & No of participants & No of studies \\
\hline \multicolumn{6}{|c|}{ Untreated quitters (weight concerned and non-weight concerned) } \\
\hline Month 1 & $1.12(0.76$ to 1.47$)$ & 1.41 & 57 & 135 & 6 \\
\hline Month 2 & 2.26 (1.98 to 2.54$)$ & 1.94 & 64 & 556 & 16 \\
\hline Month 3 & 2.85 (2.42 to 3.28$)$ & 2.79 & 84 & 776 & 25 \\
\hline Month 6 & 4.23 (3.69 to 4.77$)$ & 4.21 & 52 & 409 & 18 \\
\hline Month 12 & 4.67 (3.96 to 5.38$)$ & 4.72 & 69 & 514 & 25 \\
\hline \multicolumn{6}{|c|}{ Quitters treated with nicotine replacement therapy } \\
\hline Month 1 & $0.96(0.70$ to 1.23$)$ & 1.65 & 51 & 257 & 4 \\
\hline Month 2 & 2.00 (1.72 to 2.27$)$ & 2.64 & 65 & 1174 & 10 \\
\hline Month 3 & 2.29 (1.68 to 2.89$)$ & 2.52 & 93 & 899 & 11 \\
\hline Month 6 & 3.65 (3.17 to 4.12$)$ & 4.04 & 76 & 1121 & 17 \\
\hline Month 12 & $4.86(4.34$ to 5.38$)$ & 4.53 & 71 & 1138 & 19 \\
\hline \multicolumn{6}{|c|}{ Quitters treated with bupropion ( $300 \mathrm{mg} /$ day $)$} \\
\hline Month 1 & Not determined & Not determined & Not determined & Not determined & Not determined \\
\hline Month 2 & $1.36(1.16$ to 1.56$)$ & 2.63 & 0 & 377 & 4 \\
\hline Month 3 & 2.31 (1.42 to 3.21$)$ & 2.87 & 77 & 244 & 4 \\
\hline Month 6 & $2.71(0.84$ to 4.59$)$ & 5.70 & 61 & 48 & 4 \\
\hline Month 12 & 4.08 (3.44 to 4.71$)$ & 4.86 & 0 & 183 & 5 \\
\hline \multicolumn{6}{|c|}{ Quitters treated with varenicline (2 mg/day) } \\
\hline Month 1 & Not determined & Not determined & Not determined & Not determined & Not determined \\
\hline Month 2 & 2.19 (1.62 to 2.77$)$ & 3.51 & 0 & 127 & 2 \\
\hline Month 3 & 2.12 (1.74 to 2.50$)$ & 2.67 & 81 & 1052 & 9 \\
\hline Month 6 & 4.03 (3.66 to 4.40$)$ & 3.30 & 0 & 301 & 1 \\
\hline Month 12 & 4.17 (1.64 to 6.71$)$ & 5.31 & 91 & 174 & 3 \\
\hline
\end{tabular}


Table 4| Subgroup analyses for untreated quitters, by time point

\begin{tabular}{|c|c|c|c|c|}
\hline & Mean $(95 \% \mathrm{Cl})$ & $\mathrm{I}^{2}(\%)$ & No of studies & $\mathbf{P}$ \\
\hline \multicolumn{5}{|l|}{1 months after cessation } \\
\hline Weight concerned & 0.81 (0.61 to 1.02 ) & 0 & 2 & \multirow[t]{2}{*}{0.04} \\
\hline Not selected for weight concern & $1.46(1.08$ to 1.84$)$ & 0 & 4 & \\
\hline \multicolumn{5}{|l|}{2 months after cessation } \\
\hline Weight concerned & 1.58 (1.21 to 1.96$)$ & 26 & 3 & \multirow[t]{2}{*}{0.01} \\
\hline Not selected for weight concern & 2.46 (2.25 to 2.69$)$ & 24 & 13 & \\
\hline \multicolumn{5}{|l|}{3 months after cessation } \\
\hline Weight concerned & 3.24 (2.51 to 3.98 ) & 54 & 5 & \multirow[t]{2}{*}{0.38} \\
\hline Not selected for weight concern & 2.77 (2.29 to 3.24$)$ & 83 & 20 & \\
\hline \multicolumn{5}{|l|}{6 months after cessation } \\
\hline Weight concerned & 4.71 (3.47 to 5.95$)$ & 55 & 7 & \multirow[t]{2}{*}{0.14} \\
\hline Not selected for weight concern & 4.06 (3.49 to 4.65$)$ & 51 & 11 & \\
\hline \multicolumn{5}{|l|}{12 months after cessation } \\
\hline Weight concerned & 4.22 (2.71 to 5.73$)$ & 50 & 6 & \multirow[t]{2}{*}{0.96} \\
\hline Not selected for weight concern & 4.79 (3.98 to 5.60$)$ & 73 & 19 & \\
\hline
\end{tabular}




\section{Figures}

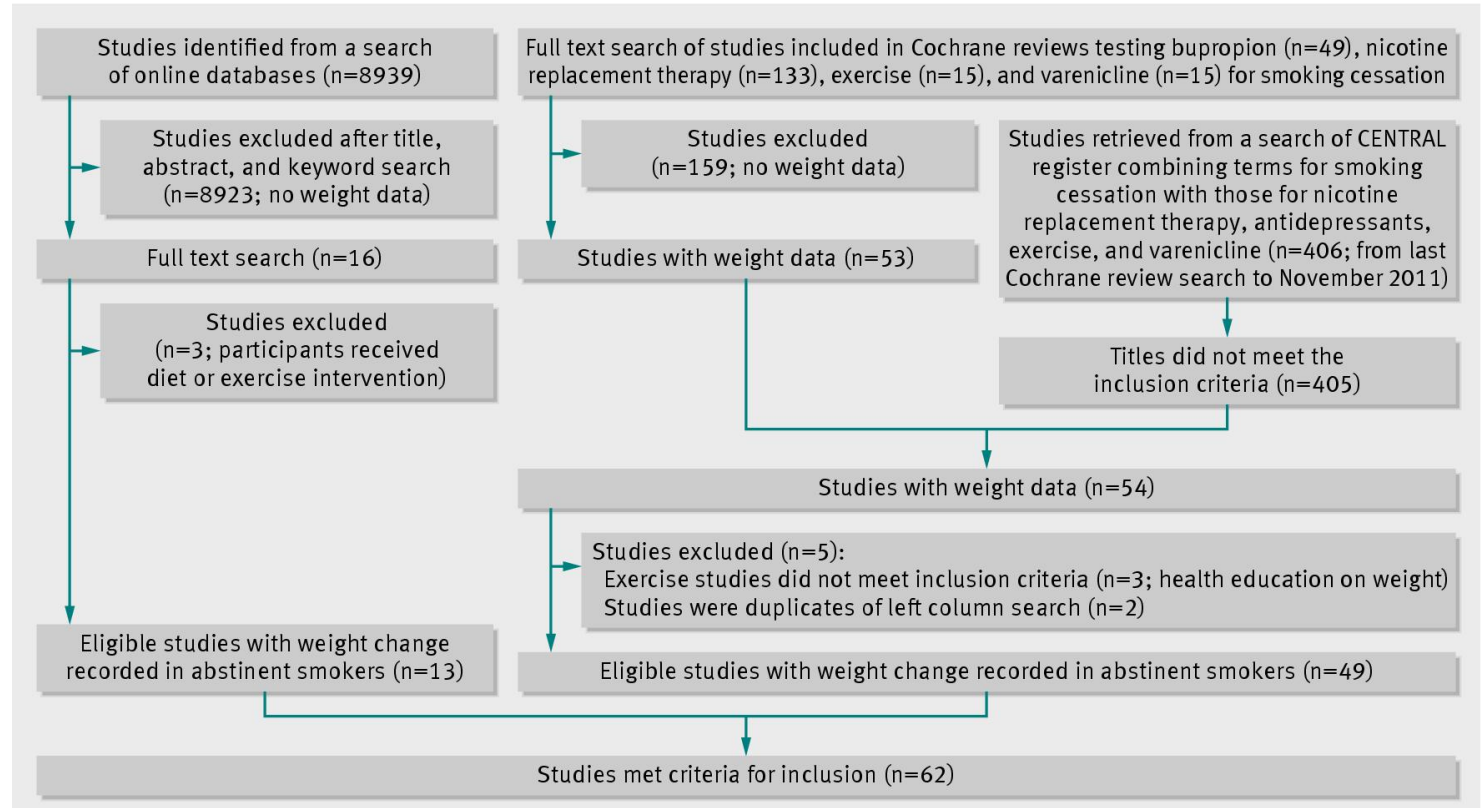

Fig 1 Study selection for inclusion in meta-analysis 


\begin{tabular}{|c|c|c|c|}
\hline Study & $\begin{array}{c}\text { No of } \\
\text { participants }\end{array}$ & $\begin{array}{c}\text { Mean weight } \\
\text { change }(95 \% \mathrm{Cl})\end{array}$ & $\begin{array}{c}\text { Mean weight } \\
\text { change }(95 \% \mathrm{Cl})\end{array}$ \\
\hline \multicolumn{4}{|l|}{ Month 1} \\
\hline Garvey et al 2000 & 47 & & 1.50 (1.03 to 1.97$)$ \\
\hline Hjalmarson et al 1997 & 22 & 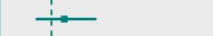 & $1.40(0.77$ to 2.03$)$ \\
\hline Klesges et al 1990 & 12 & $\rightarrow$ & 0.72 (0.13 to 1.31$)$ \\
\hline Klesges et al 1995 & 28 & $\rightarrow$ & $0.78(0.55$ to 1.01$)$ \\
\hline Parsons et al 2009 & 11 & & $1.79(0.52$ to 3.06$)$ \\
\hline Pirie et al 1992 & 15 & : & $1.10(0.19$ to 2.01$)$ \\
\hline Subtotal $\left(I^{2}=57 \%, p=0.000\right)$ & 135 & $<$ & $1.12(0.76$ to 1.47$)$ \\
\hline \multicolumn{4}{|l|}{ Month 2} \\
\hline Cooper et al 2005 & 22 & $\longrightarrow$ & 1.82 (0.91 to 2.73$)$ \\
\hline Ehrsam et al 1991 & 11 & & 1.90 (1.01 to 2.79$)$ \\
\hline Fiore et al 1994a & 17 & & 3.20 (1.96 to 4.44$)$ \\
\hline Fiore et al 1994b & 11 & & 2.80 (1.88 to 3.72$)$ \\
\hline Hall et al 1992 & 31 & 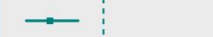 & $1.12(0.58$ to 1.65$)$ \\
\hline Hjalmarson et al 1997 & 22 & & 1.90 (1.02 to 2.78$)$ \\
\hline Hurt et al 1997 & 16 & & 2.90 (1.97 to 3.83$)$ \\
\hline Niaura et al 2002 & 46 & & 2.60 (2.08 to 3.12$)$ \\
\hline Nides et al 2006 & 10 & & $4.00(2.65$ to 5.35$)$ \\
\hline Norregaard et al 1996 & 15 & & 1.70 (1.14 to 2.26$)$ \\
\hline O’Malley et al 2006 & 34 & & $1.90(1.23$ to 2.57$)$ \\
\hline Oncken et al 2006 & 14 & & 2.14 (0.90 to 3.38$)$ \\
\hline Piper et al 2007 & 26 & & 2.60 (1.72 to 3.48$)$ \\
\hline Tonnesen et al 1999 & 147 & $\rightarrow$ & 2.20 (1.83 to 2.57$)$ \\
\hline Transdermal Nicotine Study Group 1991 & 68 & & 2.60 (2.24 to 2.96$)$ \\
\hline Zellwegger et al 2005 & 66 & & 2.32 (1.92 to 2.72$)$ \\
\hline Subtotal $\left(I^{2}=64 \%, p=0.000\right)$ & 556 & $\downarrow$ & 2.26 (1.98 to 2.54$)$ \\
\hline \multicolumn{4}{|l|}{ Month 3} \\
\hline Abelin et al 1989 & 45 & & $4.40(3.76$ to 5.04$)$ \\
\hline Gonzales et al 2006 & 61 & & 2.92 (1.93 to 3.91$)$ \\
\hline Gourlay et al 1995 & 6 & & $1.90(-0.58$ to 4.38$)$ \\
\hline Gross et al 1995 & 7 & & 2.49 (1.35 to 3.63$)$ \\
\hline Hjalmarson et al 1997 & 22 & & 2.90 (1.81 to 3.99$)$ \\
\hline Jorenby et al 2006 & 60 & & 3.15 (2.11 to 4.19$)$ \\
\hline Levine et al 2010 & 13 & & 3.77 (0.99 to 6.55$)$ \\
\hline Marcus et al 1999 & 13 & & 5.36 (1.59 to 9.13$)$ \\
\hline Nakamura et al 2007 & 51 & $\rightarrow$ & 1.48 (1.05 to 1.91$)$ \\
\hline Niaura et al 2008 & 9 & & $3.80(2.23$ to 5.04$)$ \\
\hline Norregaard et al 1996 & 13 & & 1.50 (1.63 to 2.83$)$ \\
\hline Perkins et al 2001 & 16 & & $3.70(0.99$ to 5.17$)$ \\
\hline Richmond et al 1994 & 22 & & 3.15 (0.96 to 4.67$)$ \\
\hline Rigotti et al 2006 & 25 & & 2.40 (2.01 to 3.81$)$ \\
\hline Rigotti et al 2010 & 48 & & $1.70(2.92$ to 2.44$)$ \\
\hline Shiffman et al 2002a & 99 & & 2.54 (3.15 to 3.07$)$ \\
\hline Shiffman et al 2002b & 63 & & 3.59 (2.68 to 4.26$)$ \\
\hline Spring et al 1995 & 15 & $\rightarrow$ & 3.50 (2.10 to 3.85$)$ \\
\hline Spring et al 2004 & 10 & & 3.71 (2.39 to 4.47$)$ \\
\hline Stapleton et al 1995 & 41 & & 2.80 (1.09 to 3.50$)$ \\
\hline Tashkin et al 2010 & 22 & & $3.60(2.39$ to 4.81$)$ \\
\hline Tonnesen et al 1991 & 7 & & 2.50 (1.09 to 3.91$)$ \\
\hline Tonnesen et al 1993 & 18 & & $3.80(2.92$ to 4.68$)$ \\
\hline Tsai et al 2008 & 40 & $\rightarrow$ & 1.59 (1.06 to 2.12$)$ \\
\hline Wang et al 2009 & 50 & $\rightarrow$ & 1.38 (0.68 to 2.08$)$ \\
\hline Subtotal $\left(I^{2}=84 \%, P=0.000\right)$ & 776 & $\dot{\alpha}$ & 2.85 (2.42 to 3.28$)$ \\
\hline
\end{tabular}

Fig 2 Meta-analyses of mean $(95 \% \mathrm{Cl})$ change in weight $(\mathrm{kg})$ from baseline to one, two, and three month follow-up in abstinent untreated smokers. For the Shiffman studies, smokers were stratified and received two different treatments on the basis of nicotine dependence level (separated in "a" and "b" groups). For the Fiore studies, "a" and "b" refer to two separate studies reported in the same article 


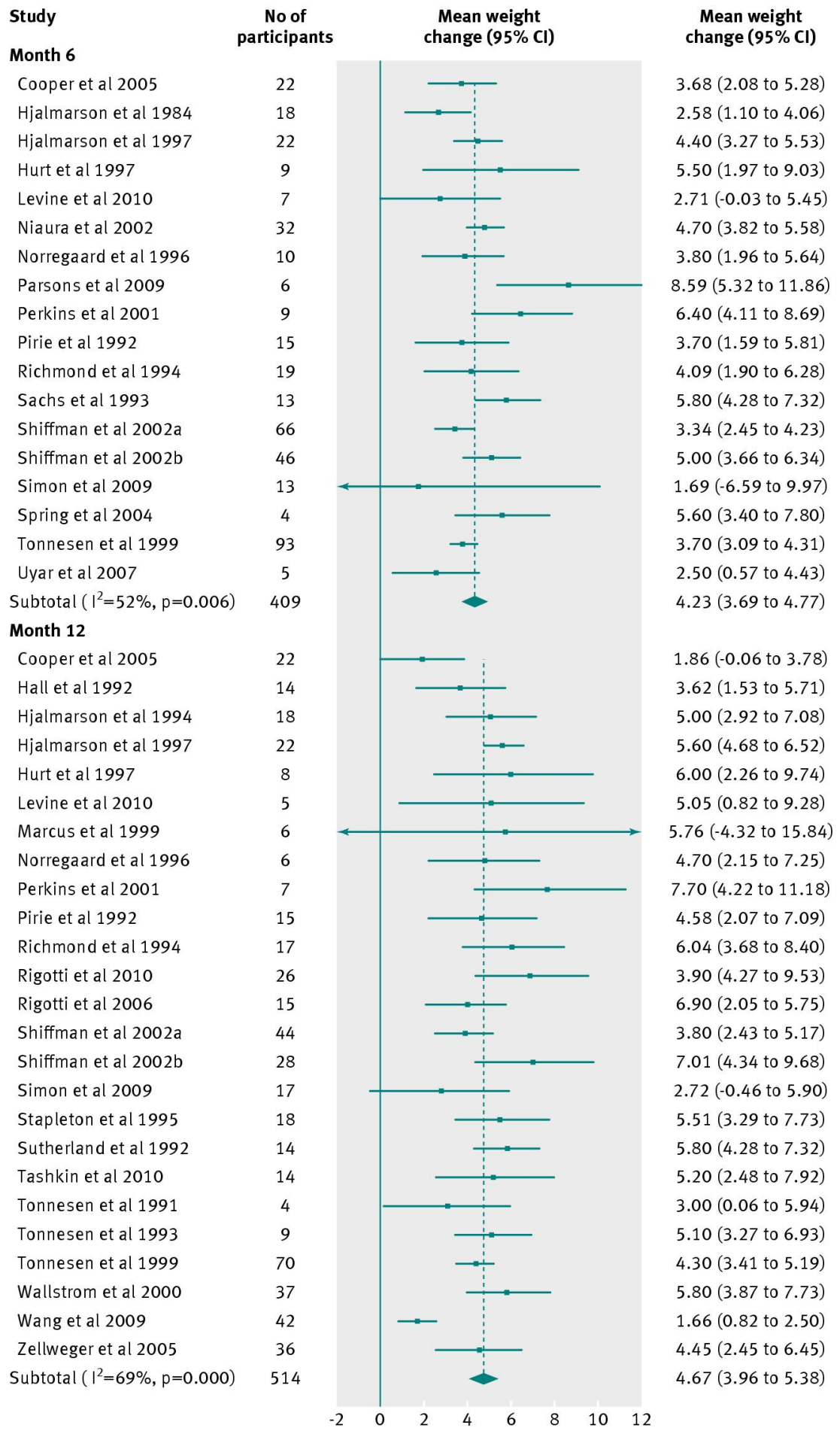

Fig 3 Meta-analyses of mean $(95 \% \mathrm{Cl})$ change in weight $(\mathrm{kg})$ from baseline to six and 12 month follow-up in abstinent untreated smokers. For the Shiffman studies, smokers were stratified and received two different treatments on the basis of nicotine dependence level (separated in "a" and "b" groups) 


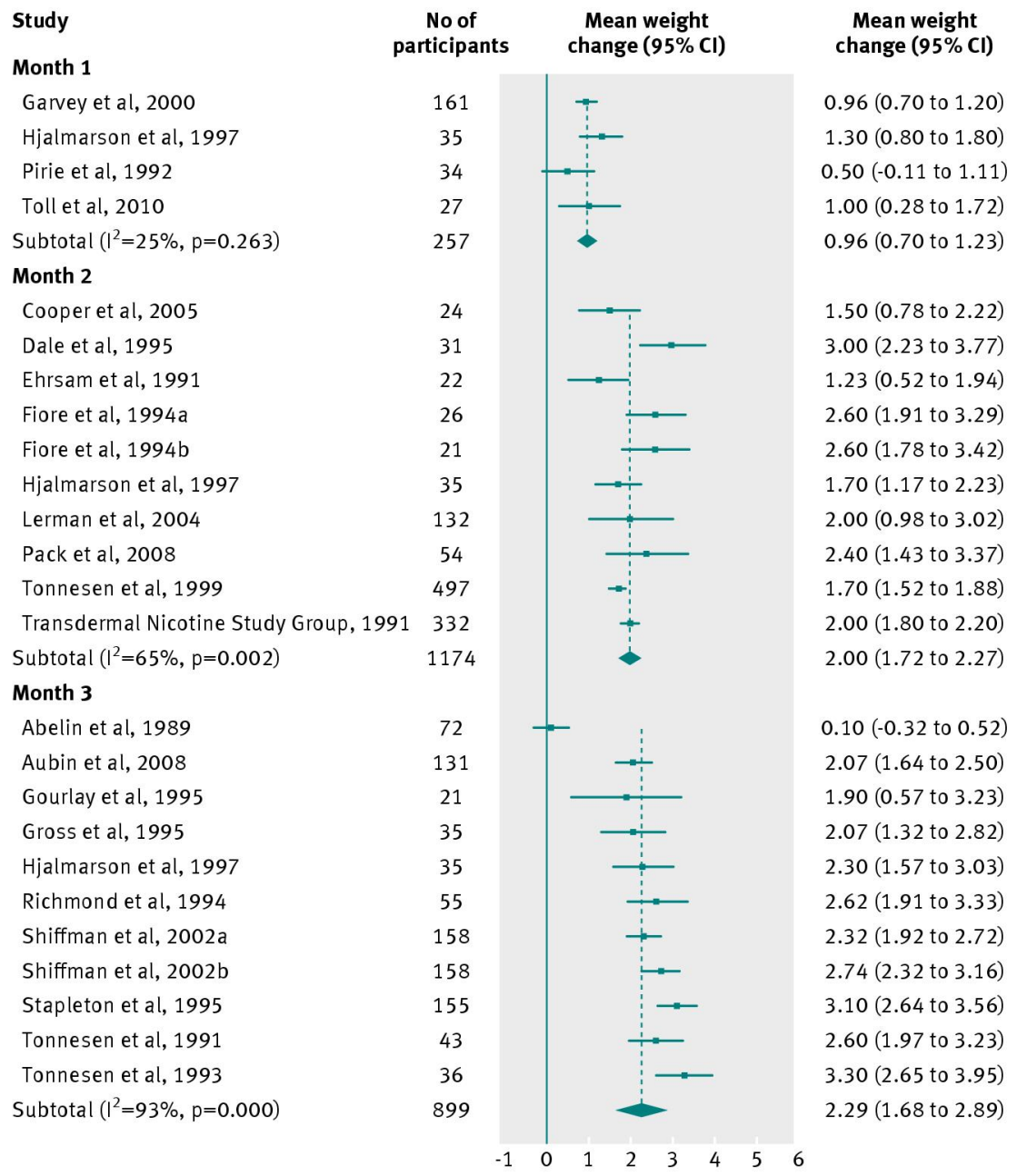

Fig 4 Meta-analyses of mean $(95 \% \mathrm{Cl})$ change in weight $(\mathrm{kg})$ from baseline to one, two, and three month follow-up in abstinent smokers treated with nicotine replacement therapy (any dose, any regimen). For the Shiffman studies, smokers were stratified and received two different treatments on the basis of nicotine dependence level (separated in "a" and "b" groups). For the Fiore studies, "a" and "b" refer to two separate studies reported in the same article 


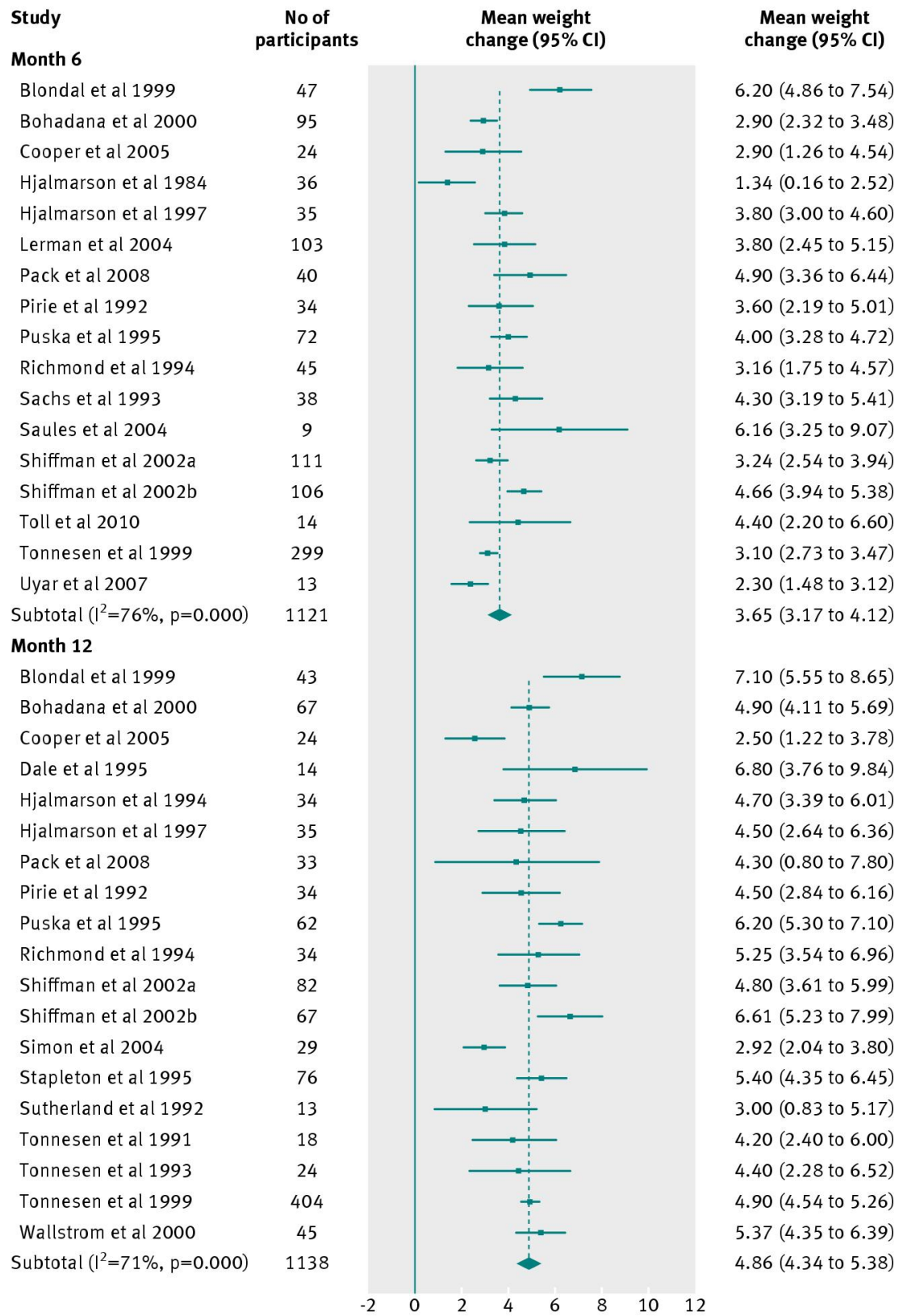

Fig 5 Meta-analyses of mean $(95 \% \mathrm{Cl})$ change $\mathrm{n}$ weight $(\mathrm{kg})$ from baseline to six and 12 month follow-up in abstinent smokers treated with nicotine replacement therapy (any dose, any regimen). For the Shiffman studies, smokers were stratified and received two different treatments on the basis of nicotine dependence level (separated in "a" and "b" groups) 


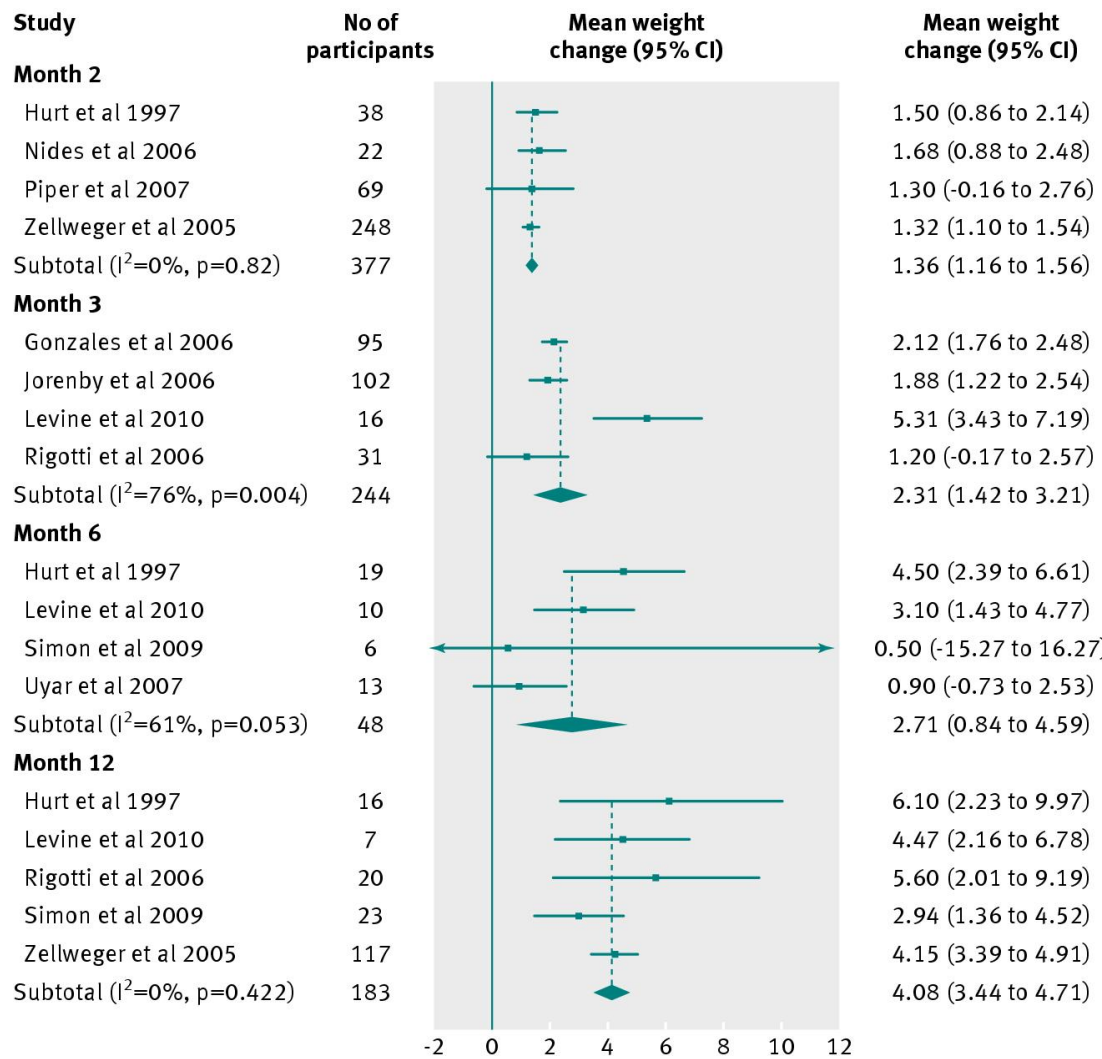

Fig 6 Meta-analyses of mean $(95 \% \mathrm{Cl})$ change in weight $(\mathrm{kg})$ from baseline to two, three, six, and 12 month follow-up in abstinent smokers treated with bupropion (300 mg/day)

\begin{tabular}{|c|c|c|c|}
\hline Study & $\begin{array}{c}\text { No of } \\
\text { participants }\end{array}$ & $\begin{array}{c}\text { Mean weight } \\
\text { change }(95 \% \mathrm{Cl})\end{array}$ & $\begin{array}{c}\text { Mean weight } \\
\text { change }(95 \% \mathrm{Cl})\end{array}$ \\
\hline Nides et al 2006 & 24 & $\rightarrow$ & 1.96 (1.04 to 2.88$)$ \\
\hline Oncken et al 2006 & 103 & - & 2.34 (1.61 to 3.07 ) \\
\hline Subtotal $\left(l^{2}=0 \%, p=0.53\right)$ & 127 & $\dot{\alpha}$ & 2.19 (1.62 to 2.77$)$ \\
\hline \multicolumn{4}{|l|}{ Month 3} \\
\hline Aubin et al 2008 & 188 & - & 2.02 (1.69 to 2.35 ) \\
\hline Gonzales et al 2006 & 155 & - & 2.37 (1.94 to 2.80$)$ \\
\hline Jorenby et al 2006 & 151 & $\rightarrow$ & 2.89 (2.42 to 3.36$)$ \\
\hline Nakamura et al 2007 & 85 & - & 1.37 (0.94 to 1.80$)$ \\
\hline Niaura et al 2008 & 32 & $\longrightarrow$ & 4.00 (2.44 to 5.56$)$ \\
\hline Rigotti et al 2010 & 161 & + & 2.20 (1.78 to 2.62$)$ \\
\hline Tashkin et al 2011 & 103 & - & 2.50 (1.96 to 3.04$)$ \\
\hline Tsai et al 2008 & 75 & $\rightarrow$ & $1.29(0.74$ to 1.84$)$ \\
\hline Wang et al 2009 & 82 & $-i$ & 1.58 (0.98 to 2.18$)$ \\
\hline Subtotal $\left(1^{2}=76 \%, p=0.004\right)$ & 1032 & 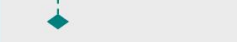 & 2.12 (1.74 to 2.50$)$ \\
\hline \multicolumn{4}{|l|}{ Month 6} \\
\hline \multirow[t]{2}{*}{ Tonstad et al 2006} & 301 & 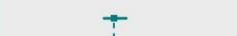 & 4.03 (3.66 to 4.40$)$ \\
\hline & 301 & - & 4.03 (3.66 to 4.40$)$ \\
\hline \multicolumn{4}{|l|}{ Month 12} \\
\hline Rigotti et al 2010 & 67 & $\longrightarrow$ & $5.20(4.15$ to 6.25$)$ \\
\hline Tashkin et al 2011 & 44 & & $5.70(2.95$ to 8.45$)$ \\
\hline Wang et al 2009 & 63 & $\longrightarrow$ & 2.07 (1.21 to 2.93$)$ \\
\hline Subtotal $\left(1^{2}=91 \%, p=0.000\right)$ & 174 & $\longrightarrow$ & 4.17 (1.64 to 6.71$)$ \\
\hline
\end{tabular}

Fig 7 Meta-analyses of mean $(95 \% \mathrm{Cl})$ change in weight $(\mathrm{kg})$ from baseline to two, three, and 12 month follow-up in abstinent smokers treated with varenicline ( $2 \mathrm{mg} /$ day) 


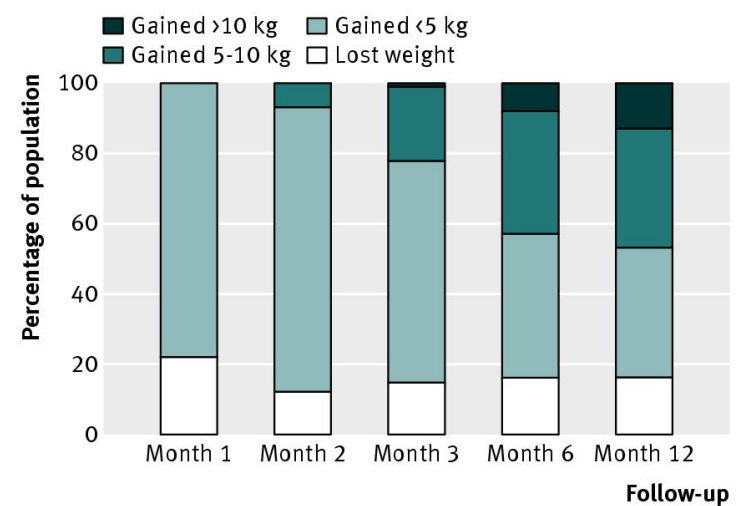

Fig 8 Percentage of untreated quitting population who would be expected to lose weight, gain $<5 \mathrm{~kg}$, gain 5-10 kg, or gain $>10 \mathrm{~kg}$ over 12 months

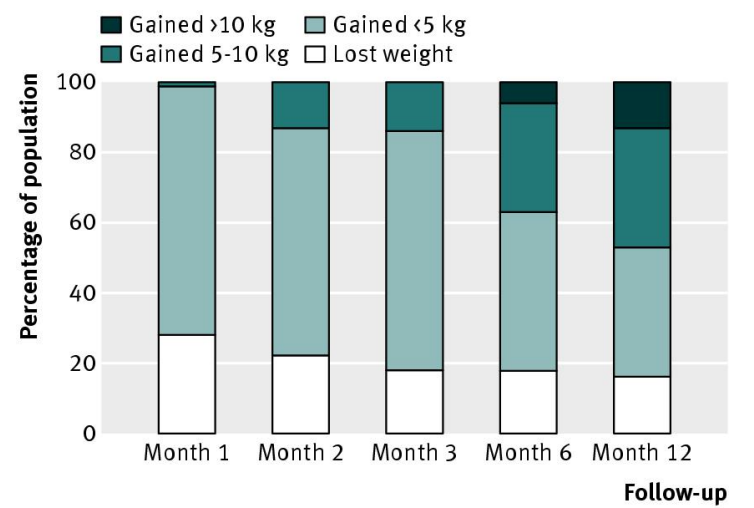

Fig 9 Percentage of quitting population treated with nicotine replacement therapy who would be expected to lose weight, gain $<5 \mathrm{~kg}$, gain $5-10 \mathrm{~kg}$, or gain $>10 \mathrm{~kg}$ over 12 months

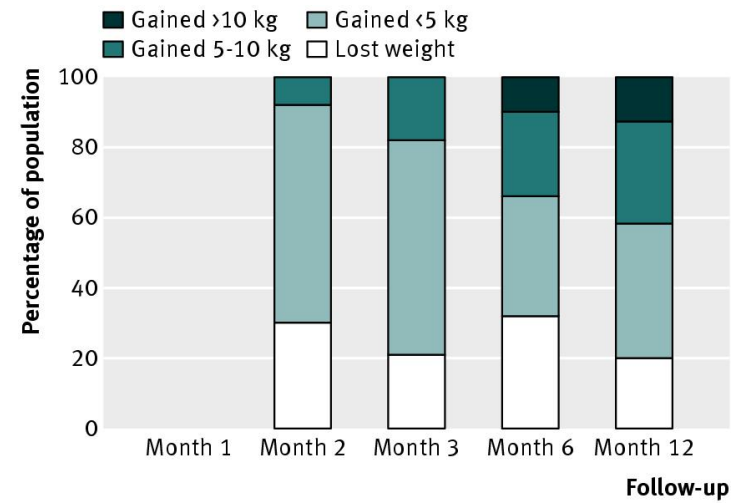

Fig 10 Percentage of quitting population treated with bupropion who would be expected to lose weight, gain $<5 \mathrm{~kg}$, gain $5-10 \mathrm{~kg}$, or gain $>10 \mathrm{~kg}$ over 12 months 


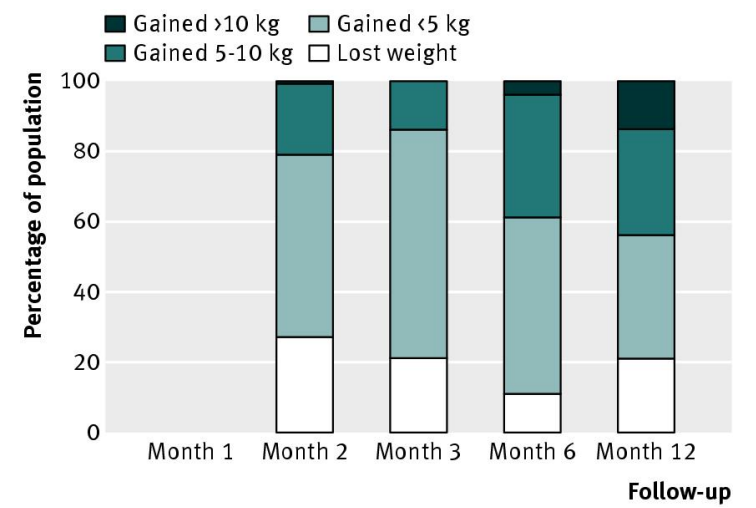

Fig 11 Percentage of quitting population treated with varenicline who would be expected to lose weight, gain $<5 \mathrm{~kg}$, gain $5-10 \mathrm{~kg}$, or gain $>10 \mathrm{~kg}$ over 12 months 